\title{
SEVGILIYE VE DOST(LAR)A MEKTUPLAR: MÜNŞEÂT-I NAHîFî
}

$\ddot{O} \mathbf{z}$

\section{Ramazan EKİNCi*}

Nahîfî mahlaslı şairlerin en meşhuru olan ve edebiyat tarihimizde "Mesnevi Mütercimi" unvanıyla bilinen Mehmed Süleyman Nahîfî (?-1738), bir asra yaklaşan uzun bir ömür sürmüş; bu süre içerisinde çeşitli devlet görevlerinde (yeniçerilik, sefir kâtipliği, şıkk-1 sânî defterdarlığı $v b$.) bulunmanın yanı sıra, hem nazım hem de nesir alanında birçok eser kaleme almıştır. Hayatı, sanatı ve eserleriyle alâkalı birçok makale yazılan, tez hazırlanan Nahîfî’nin mensur telifatından Münşeât, bugüne kadar pek bilinmeyen ve üzerinde fazla bir çalışma yapılmayan mektuplardan meydana gelmektedir.

Farklı zamanlarda yazılmış sekiz mektuptan oluşan Münşeât'taki beş mektup, şairin sevdiğine yazdığ âş̧ıâne söyleyiş ve edebî ifadelerle yüklü samimi hislerini yansıtmaktadır. Geriye kalan üç mektuptan ikisini bir dostuna veya dostlarına yazdığı, diğerini ise hüner gösterme maksadıyla kaleme aldığı düşünülmektedir. Münşeât'ta yer alan şiirlerin (1'i Farsça olan 18 müfred, 17 beyitlik bir kıta, tamamlanmamış 4 gazel, biri Hamamnâme olan 2 gazel) hiçbirinin şairin Dîvân'ında yer almaması, eserin kıymetini daha da artırmaktadır. $\mathrm{Bu}$ makalede Nahîfi'nin Münşeât' ${ }^{\prime} 1$ incelenecek; metnin nüsha(ları) ve muhtevası hakkında ayrıntılı bilgi verilecektir. Çalışmanın sonunda şairin hayatı ve edebî şahsiyetine yönelik bazı yeni bilgilerin bulunduğu Münşeât' 1 transkripsiyonlu metni verilecektir.

Anahtar Sözcükler: Süleyman Nahîfî, Münşeât, Mektup, XVIII. yüzy1l.

\section{LETTERS TO THE DARLING AND FRFENDS: MÜNŞEÂT-I NAHÎFî}

\begin{abstract}
Among the most well-known poets who uses the pen name of Nahîfî is Mehmed Süleyman Nahîfî. In our literary history he is known as "translator of Masnavi" (died in 1738). He lived a long life nearly acentury and during his life he served as various stste officials. (janissary, ambassador clerk, şıkk-1 sânî official who heads a provincial treasury) In addition he produced many literary Works both in the field of verse and prose. There are many articles and thesis about his life, art and Works. However the Münşeât, which is written in prose, includes unknown and unstudied literary letters.
\end{abstract}

Münşeât contains 8 letters which are written in different times. Among these five them reflects the poets sincere feelins with amorous and literary statements. Two of the remaining three are written to a friend and the last one ia thought to be written for the purpose of demonstrating his skills. None of the poems in Münşeât take part in his Divvân, as a result of this the value the work increases.(one in persian language consists of 17 mufred, one stanza with 17 couplets, unfinished 4 gazhel, 2 gazhel one of which is Hammâmnâme) In this article the Münşeât of Nahîfî wiil be examined and detailed information about the dittos and contents of the text will be presented. At the end of this study the transcriptional text of Münşeât, which contains information about the life and literary figüre of the poet, will be introduced.

Keywords: Süleyman Nahîfî, Münşeât, Letter, XVIII ${ }^{\text {th }}$ century.

\footnotetext{
${ }^{*}$ Dr.; Celal Bayar Üniversitesi Fen-Edebiyat Fakültesi Türk Dili ve Edebiyatı Bölümü, ramazanekinci@ hotmail.com.
} 


\section{Giriş:}

Arapça bir kelime olan "inşâ", “نشأن" kökünden türetilmiş; sözlüklerde önceleri "ortaya çıkarmak, icat ve ihdas etmek, yaratmak" manalarının karşılığı olarak yer alırken, daha sonra "kurmak, üretmek ve yazmak" gibi anlamlar kazanmış bir sözcüktür. Zamanla bu ikinci kullanımdan hareketle "yazmak, yazma sanatı ve kompozisyon" gibi anlamlar yüklenerek resmî ve özel yazışmaların belirli bir usule göre yapılmasının inceliklerini ve mektup yazma sanatını ifade eden bir terim haline gelmiştir. Bu sanatı konu edinen disipline "ilmü'l-inşâ", inşâ yazarına "münş̂”", bu ilmin kurallarına uygun olarak hazırlanmış metinlere de "münşeât" adı verilmiştir.

Edebiyat tarihimiz içinde en eski tarihlisi XV. asrın başlarına ait olan mektup türü, ${ }^{2}$ zamanla gelişmiş; bir mektubun nasıl yazılması, mektup yazılırken nelere dikkat edilmesi gerektiği $v b$. hususları ayrıntılı şekilde anlatan didaktik mahiyette eserler kaleme alınmıştır. Bunların yanı sıra edebiyat tarihimizin bazı mühim sîmâlarının, inşâ alanında önemli bir yere sahip, itinalı bir dil ve sanat kaygısı güdülen bir üslûpla yazdıkları mektupların derlenmesiyle meydana gelen münşeâtlar da vardır. Muhtevaları itibariyle edebî, tarihî ve didaktik münşeâtlar olarak sınıflandırılan ${ }^{3}$ bu eserlerin edebî olanları Ali Şîr Nevâyî, ${ }^{4}$ Lâmi ${ }^{‘} \hat{,},{ }^{5}$ Veysî, ${ }^{6}$ Nergisî, ${ }^{7}$ Nâbî ${ }^{8}$ ve Kânî gibi klasik Türk edebiyatının önde gelen şair ve yazarlarına aittir. Kaleme aldığı birçok dinî eserin yanı sıra Mevlânâ'nın Mesnevî’sini manzum olarak Türkçeye tercüme eden ve bu sebeple edebiyat tarihimizde "Mesnevî mütercimi” unvanıyla anılan Nahîfî Süleyman Efendi’nin de rahatlıkla edebî münşeâtlar grubuna dâhil edilebilecek bir münşeâtı vardır.

\footnotetext{
${ }^{1}$ İsmail Durmuş, “İnşâ”, Diyanet İslâm Ansiklopedisi, İstanbul 2000, C. 22, s. 334.

${ }^{2}$ Agâh Sırrı Levend, Türk Edebiyatı Tarihi, TTK Yay., Ankara 2008, s. 113. II. Murad ve Fatih zamanında yazılmış mektupları ihtiva eden Yahya bin Mehmed'e ait Menâhicü'l-İnşâ adlı eser, bilinen en eski münşeat mecmuasıdır.

${ }^{3} \mathrm{Bu}$ sınıflandırma "Münşeât" türü ile alâkalı en kapsamlı çalışmanın sahibi Halil İbrahim Haksever'e aittir. Münșeâtlarda muhteva, tasnif, yazım teknikleri, üslup; edebiyat tarihimizde münşeâtların kronolojik dağılımı $v b$. konular hakkında ayrıntılı bilgi için bk. Halil İbrahim Haksever, Eski Türk Edebiyatında Münşeâtlar ve Nergisî'nin Münşeâtı, İnönü Üniversitesi SBE, Basılmamış Doktora Tezi, Malatya 1995.

${ }^{4}$ A. Deniz Abik, Ali Şîr Nevâŷ̂'nin Risâleleri: Târîh-i Enbiyâ ve Hükemâ, Târîh-i Mülûk-i Acem, Münşeât (MetinGramatikal İndeks-Sözlük), Ankara Üniversitesi SBE, Basılmamış Doktora Tezi, Ankara 1993.

${ }^{5}$ Hasan Ali Esir (haz.), Münşeât-ı Lâmî̀: (Lâmî̀ Çelebi'nin mektupları)-İnceleme-Metin-İndeks-Sözlük, Karadeniz Teknik Üniversitesi Yay., Trabzon 2006.

${ }^{6}$ Ahmet Kılıç (haz.), Münşe'at-ı Veysî (Inceleme-Transkripsiyonlu ve Tenkitli Metin), Erciyes Üniversitesi SBE, Devam Eden Doktora Tezi.

${ }^{7}$ Haksever, agt.

${ }^{8}$ Adnan Oktay (haz.), Nâbî̀nin Münşeât'ı: Inceleme-Metin, Dicle Üniversitesi SBE, Basılmamış Doktora Tezi, Diyarbakır 2014.

${ }^{9}$ Güllü Araç (haz.), “Tokatı Kânî'nin Münşeâtı ve İncelemesi”, Ege Üniversitesi SBE, Devam Eden Doktora Tezi.
} 


\section{Nahîfî'nin Münşeât'ı:}

Ziya Paşa'ya göre mesnevi türünde hüner sahibi ve kudretli bir şair; ${ }^{10}$ Muallim Nâcî'ye göre İstanbul'da yetişen şairlerin en büyüğ̈̈; ${ }^{11}$ Abdülbâkî Gölpınarlı'ya göre XVIII. asır divan şiirinin Nedîm ve Şeyh Gâlib'den sonra en meşhuru, hatta söyleyiş ve dil bakımından onlardan da üstünü ${ }^{12}$ olan Nahîfî’nin ismi Mehmed Süleymân'dır. Babasının ismi Abdurrahman (ö.170001), dedesinin ismi Sâlih Efendi'dir. Şairin İstanbul'da doğduğu bilgisi üzerinde kaynaklar ittifak eder. İhtilaflı olan bahis ise şairin doğum tarihidir.

Nahîfî’nin doğum tarihi hakkında, şairin hayatı ve eserleri üzerinde çalışma yapanlar çeşitli görüşler beyân etmişlerdir. Hilyetü'l-Envâr'1 1099'da tamamlayan Nahîfî, eserin giriş kısımlarında metni 24 yaşında iken yazdığını ifade etmiş, buradan hareketle araştırmacılar şairin doğum tarihini 1075/1664-65 olarak tespit etmişlerdir. ${ }^{13}$ Ancak gözden kaçırılan nokta Nahîfî’nin eserini 24 yaşında bitirdiği değil, yazmaya başladığı bilgisidir. Bu bilgi dikkate alındığında, "bir şair veya yazar başladığı bir eseri aynı yıl içinde bitirmek zorunda mıdır?" sorusu yanıtsız kalmaktadır. Nahîfî’nin hemşehrîleri ve muasırları olan Hâfız Hüseyin Ayvansarâyî (ö. 1787) ve Müstakîmzâde Süleyman Sa'deddîn (1719-1788) gibi muteber kabul edilen biyografi yazarlar1, şairin doksan yaşının üzerinde iken vefat ettiğini söylerler. ${ }^{14}$ Ayrıca XIX. asır şuarâ tezkire yazarlarından Sahhâflar Şeyhizâde Es‘ad Efendi (1789-1848), Nahîfi’'nin doksan yaşında iken, Hacı Mehmed Tevfîk (1814-1857) ise doksan yaşın üzerinde iken vefat ettiğini bildirir. Nahîfî’nin doğum ve ölüm tarihini bildiren yegâne kaynak ise Şakâ'iku'n-Nu'mâniyye zeyillerinin sonuncusu olan Findıklılı İsmet Efendi'nin (1845-1904) kaleme aldığı Tekmiletü'ş-Şakâ'ik fi Hakk-ı Ehli'l-Hakâ'ik adlı eserdir. İsmet Efendi, Nahîfî’nin 1056/1646-47 y1lında doğduğunu ve 95 yaşında iken $1151 / 1738$ 'de vefat ettiğini açıklar. ${ }^{15}$ Hemen hemen bütün tarihî biyografik metinlerin, Nahîfî'nin 90 yaş veya bu yaşın üzerinde iken vefat ettiği bilgisinde ittifak etmeleri,

\footnotetext{
${ }^{10}$ Ziyâ Paşa, Mukaddime-i Harâbât, Matba'a-i Ebuzziyâ, İstanbul 1311, s.76.

${ }^{11}$ Muallim Nâcî, Osmanlı Şairleri, İstanbul 1307, s. 102.

${ }^{12}$ Abdülbâkî Gölpınarlı, Divan Şiiri, XVIII. Yüzyıl, Varlık Yayınları, İstanbul 1955, s. 13.

${ }^{13}$ Mustafa Uzun, "Nahîfî”, Diyanet İslâm Ansiklopedisi, İstanbul 2006, C 32, s. 298;

Murat Karavelioğlu, "Nahîfî Süleyman", Türk Edebiyatı Issimler Sözlüğ̈̈ http://www.turkedebiyatiisimlersozlugu.com/index.php?sayfa=detay\&detay=2663 [erişim tarihi: 01.11.2014] Tamamı 4073 beyit olan mesnevinin 420. beytinde "Bist ü çârümde iken sinn ü sâl / Ya"ni zuhûr itdi bu şîrn-makâl" bu ifadelerden hareketle eseri 24 yaşında tamamlandığ iddia edilmiştir. Eserin tenkitli metni için $b k$. Mehtap Erdoğan (hzl.), Türk Edebiyatında Manzum Hilyeler, Cumhuriyet Üniversitesi SBE, Dr. Tezi, Sivas 2011, s. 637-985.

${ }^{14}$ Ramazan Ekinci (haz.), Hâfiz Hüseyin Ayvansarâyî, Vefeyât-ı Ayvansarâyî, Buhara Yay., İstanbul 2013, s. 105; Müstakimzâde Süleyman Sa'deddîn, Mecelletü'n-Nisâb, Süleymaniye Ktp., Hâlet Efendi, nr. 628, vr. 420b; İbnülemin Mahmud Kemâl İnal (haz.), Müstakimzâde Süleyman Sa deddîn, Tuhfe-i Hattâtîn, Devlet Matbaası, İstanbul 1928, s. 213.

${ }^{15}$ Fındıklı1ı İsmet, Tekmiletü 'ş-Şakā' ’k fí Ehli'l-Hakā ’ik, (Tıpkıbasım: A. Özcan), Çağrı Yay., İstanbul 1989, s. 142.
} 
Fındıklılı İsmet'in verdiği bilgilerin sıhhatini teyit eder niteliktedir. Aksi bir iddia bulunmadığı ve elde bulunan bütün deliller Fındıklılı İsmet'in bildirdiklerini desteklediği için Nahîfî'nin doğum tarihini 1056/1646-47 kabul etmek gerekir. ${ }^{16}$

Nahîfî iyi bir eğitim alarak aklî ve naklî ilimlerdeki tahsilini tamamladı. Ayrıca Osmanlı devri hattatlarının üstâdları arasında yer alan Hâfız Osman Efendi'den (ö. 1698) sülüs ve nesih hatta icazet aldı. Gençlik yıllarında dergâh-1 âlî yeniçeri kalemine kâtip olarak giren şairin devlet memuriyetinin ne zaman başladığı bilinmemektedir. İyi ahlâk sahibi, azimli ve çalışkan olması hasebiyle görevi başyazıcılığa yükseltilmiş; hâcegân-1 dîvân sınıfına dâhil olmuştur. Hangi sebeple olduğu bilinmemekle birlikte 1094/1683'te Mısır'a gitmek üzere yola çıktı̆̆ında, Konya'ya da uğramıştır. Sultan II. Mustafa (ö. 1703) zamanında 1110/1699'da İran şahına resmî elçi olarak gönderilen Ebû Kavuk Mehmed Paşa'nın maiyetinde Nahîfî de bulunmuş; Revan, Tebriz, Nahcivan, Kazvin, Kum, Kâşân ve Isfahan'1 gezmiştir. Sultan III. Ahmed (ö. 1736) zamanında 1131/1719'da Avusturya kralına gönderilen heyetin içinde Nahîfî de yer almıştır. Yaklaşık 9 ay kaldıkları Viyana'dan 1132/1720'de İstanbul'a dönmüşlerdir. Vazifesini lâyıkıyla yerine getirmesi sebebiyle Nahîfî, divân-1 sultânî hâceliğinden başmukata'acıllğga yükseltildi. 1138/1725-26'da vefat eden Mustafa Safâyî Efendi'nin yerine şıkk-1 sânî defterdârlığına tayin edildi. Yaklaşık bir yıl sonra kendi isteğiyle emekliye ayrıldı.19 Cemâziyelevvel 1151/4 Eylül 1738 'de İstanbul'da vefat etti. ${ }^{17}$

Nahîfî’nin manzum ve mensur birçok eseri bulunmaktadır. Ayrıca Nahîfî mahlaslı diğer şairlere ait bazı eserler de Mehmed Süleyman Nahîfî’ye isnâd edilmiştir. Nahîfî’nin hayatı, sanatı ve eserleriyle alâkalı hazırlanan en son çalışmanın sahibi Şaban Er, Nahîfî hakkında bildirilen birçok yanlışı düzelterek şairin eserlerini şunlar olarak bildirmektedir:

Manzum eserleri arasında Dîvân, Mesnevî-i Şerîf Tercümesi, Hilyetü'l-Envâr, Hicretnâme, Mevlidü'n-Nebî, Mi 'râciyye, Zuhrü'l-Âhire, Mev'izatü’n-Nüfûs, Enfüs ü Âfâk, Âdâb-ı Tarîkat ve Kavâ'id-i Hakîkat, Mübâhese-i Kazâ ve Kader, Ka‘b bin Züheyr'in Kasîdetü’lBürde'sinin Türkçe Tahmisi, İmâm Busîrî'nin Kasîdetü'l-Bürde'sinin Türkçe Tercümesi ile Türkçe, Arapça ve Farsça Tahmisleri yer almaktadır.

\footnotetext{
${ }^{16}$ Şairin doğum tarihiyle alakalı tartışmalarda, bilhassa Ayvansarâyî ve Fındıklılı İsmet'in verdiği bilgiler gözden kaçırılmış olduğundan bu bahis üzerinde ayrıntılı durulmuştur. Makalemizin konusu doğrudan Nahîfî’nin hayatı olmadığından, bundan sonraki kısımlar kısa tutulacak ve Nahîfí'nin hayatı ve eserleriyle alakalı yapılmış en kapsamlı iki çalışma olan Âdem Ceyhan'ın "Süleyman Nahîfî ve Kasîde-i Mudariyye Tahmîsi” adlı makalesi ve Şaban Er'in Nahîfi Süleymân Efendi Külliyâtı adlı kitabından istifade edilerek özetlenecektir.

${ }^{17}$ Âdem Ceyhan, "Süleyman Nahîfî ve Kasîde-i Mudariyye Tahmîsi”, Akademik Baklş, Güz (Urfa) 1997, s. 32- 37; Şaban Er (haz.), Nahîfi Süleymân Efendi Külliyâtı, Kutupyıldızı Yay. İstanbul 2014, s. 16-36.
} 
Mensur eserleri arasında İbnü'n-Nahvî'nin Kasîdetü'l-Münferice'sinin Türkçe Şerhi, Risâle-i Hızriyye, Risâletü'l-Kalemiyye, Ravzatü's-Safâ fì Sîreti'l-Mustafâ, Âsâf-nâme, Sefâretnâme, Gazevât-ı Nebî ve Münşeât yer almaktadır. ${ }^{18}$

Nahîfî’yle alâkalı malumat veren eski harfli kaynaklarda (şuara tezkireleri, ${ }^{19}$ Mecelletü'nnisab, Osmanlı Şairleri, Osmanlı Müellifleri, Sefine-i Evliyâ, Tuhfe-i Nâilî vb. diğer biyografik kaynaklar ${ }^{20}$ ) şairin Münşeât'ı hakkında herhangi bir bilgi bulunmamaktadır. Ayrıca şairin hayatı, sanatı ve eserleri ile ilgili yazılan kitap ve makalelerde, ${ }^{21}$ bazı ansiklopedi maddelerinde; ${ }^{22}$ eserleri üzerinde hazırlanan yüksek lisans ve doktora tezlerinde ${ }^{23}$ Münşeât' 1 in ismi dahi zikredilmemiştir.

${ }^{18}$ Er, age., s. 11-13.

${ }^{19}$ Pervin Çapan (haz.), Mustafa Safâŷ,Tezkire-i Safâŷ̂, AKMB Yay., Ankara 2005, s. 649-660;

Adnan İnce (hzl.), Sâlim Efendi, Tezkiretü'ş-Şu'arâ, AKMB Yay., Ankara 2005, s. 653-658; Abdulkerim Abdulkadiroğlu (haz.), İsmâil Beliğ, Nuhbetü'l-Âsâr, AKMB Yay., Ankara 1994, s. 443-449; Bilal Güzel (haz.), Kemiksizzade M. Safvet, Nuhbetüll-Âsâr min Ferâidi'l-Eş'âr İsimli Şairler Tezkiresi, Gazi Üniversitesi SBE, Basılmamış YL Tezi, Ankara 2012, s.690-706; Rıza Oğraş (haz.), Es 'ad Efendi, Bağçe-i Safâ-enduz, Kültür Bak. ekitap [erişim tarihi: 01.11.2014] http://ekitap.kulturturizm.gov.tr/Eklenti/10734,bahcepdf.pdf?0, s.169-179; Ömer Çiftçi (haz.), Fatin Davûd, Hâtimetü'l-Eş 'âr, Kültür Bak. e-kitap [erişim tarihi: 01.11.2014] http://ekitap.kulturturizm.gov.tr/Eklenti/10736,metinpdf.pdf?0, s. 399-400; Ruhsar Zübeyiroğlu (haz.), Mehmed Tevfik Efendi, Mecmuatü’t-Terâcim, İstanbul Üni. SBE; Basılmamıș Doktora Tezi, İstanbul 1989, s. 7-9.

${ }^{20}$ Müstakimzâde Süleyman Sa'deddîn, Mecelletü'n-Nisâb, Süleymaniye Ktp., Hâlet Efendi, nr. 628, vr. 420b; İbnülemin Mahmud Kemâl İnal (haz.), Müstakimzâde Süleyman Sa 'deddîn, Tuhfe-i Hattâtîn, Devlet Matbaası, İstanbul 1928, s. 213-214; Ramazan Ekinci (haz.), Hâfiz Hüseyin Ayvansarâŷ̂, Vefeyât-ı Ayvansarâŷ̂, Buhara Yay., İstanbul 2013, s. 105; Bağdatlı İsmail Paşa, Hediyyetü'l-Ârifîn, Esmâ'ü'l-Müellifîn ve Âsârü'l-Musannifîn, Millî Eğitim Basımevi, İstanbul 1951, C. 1, s. 404; Fındıklı1ı İsmet, Tekmiletü 'ş-Şakā'ik fí Ehli'l-Hakā'ik, (Tıpkıbasım: A. Özcan), Çağrı Yay., İstanbul 1989, s. 142-145; Ahmed Rif'at, Lügât-ı Târihiyye ve Coğrafiyye, İstanbul 1300, C. 7, s. 77; E.J. Wilkinson Gibb, Osmanlı Şiir Tarihi, (çev. A. Çavuşoğlu) Akçağ Yay., Ankara 1999, C. 3, s. 323-328; Fâik Reşâd, Eslâf, 'Âlem Matba'ası, İstanbul 1312, s. 32-35; Nuri Akbayar (hzl.), Mehmed Süreyyâ, Sicill-i Osmânî, Tarih Vakfi Yurt Yay., İstanbul 1996, C. IV, s. 1223; Muallim Nâcî, Osmanlı Şairleri, İstanbul 1307, s. 101-105; Muallim Nâcî, Esâmî, İstanbul 1308, s. 319; Şemseddin Sâmî, Kāmûsü'l-A ’lâm, Mihran Matbaası, İstanbul 1316, C. 6, s. 4569; Bursalı Mehmed Tâhir, Osmanlı Müellifleri, Dersaadet 1333, C. II, 455-456; Mehmet Akkuş-Ali Yılmaz (haz.), Hüseyin Vassâf, Sefine-i Evliyâ, Kitabevi Yay., İstanbul 2011, C. 5, s. 151-157; Mehmed Nâil Tuman, Tuhfe-i Nâilî, (tıpkıbasım: C. Kurnaz-M. Tatc1), Bizim Büro Yay., Ankara 2001, C. 2, s. 4252.

${ }^{21}$ Âmil Çelebioğlu (haz.), Mesnevî-i Şerîf: Aslı ve Sadeleştirilmişiyle Manzum Nahifî Tercümesi, Sönmez Neșriyat, İstanbul 1967, C. 1, s. C-D; Âmil Çelebioğlu, "Süleyman Nahîfî ve Fazilet-i Savm (Zuhrü'l-Ahire) Adlı Eseri”, Diyanet Dergisi, S. 12, Ankara 1972, s. 342-350; Âmil Çelebioğlu, "Süleyman Nahîfí'nin Hicretü'n-Nebî'nin Adlı Mesnevîsi", Türklük Araştırmaları Dergisi, S. 2, 1986, İstanbul 1987, s. 53-87; Âmil Çelebioğlu, "Nahîfî’nin Risâle-i Hıdriyye'si", Eski Türk Edebiyatı Araştırmaları, MEB Yay., İstanbul 1998, s. 335-347; Âdem Ceyhan, "Süleyman Nahîfî ve Kasîde-i Mudariyye Tahmîsi", Akademik Bakış, Güz (Urfa) 1997, s. 32- 43; Âdem Ceyhan, "Süleyman Nahîfî'nin Mevlidü'n-Nebî Mesnevîsi”, Atatürk Üniversitesi Türkiyat Araştırmaları Enstitüsü Dergisi, S. 14, Erzurum 2000, s. 89-141.

22 Komisyon, "Nahîfî Süleyman”, Türk Dili ve Edebiyatı Ansiklopedisi, Dergâh Yay., İstanbul 1986, C. 6, s. 498; Atilla Özkırıml1, "Nahifî Süleyman”, Türk Edebiyatı Tarihi (Ansiklopedisi), İnkılap Yay., İstanbul 2004, C. 2, s. 949-950; Nilgün Açık, "Nahîfî", Türk Dünyası Edebiyatçıları Ansiklopedisi, AKMB Yay., Ankara 2006, C. 6, s. 495-496.

${ }^{23}$ Ali İrfan Aypay, Nahifí Süleyman Efendi (Hayatı, Eserleri, Edebî Kişiliği ve Divanının Tenkitli Metni), Selçuk Üniversitesi SBE, Basılmamış Doktora Tezi, Konya 1992; [Tezde, Münşeât şairin eserleri arasında zikredilmemiş; A. C. Yöntem'in verdiği bilgiler kısaca iktibas edilmiştir.]; Zekeriya Usluer, Süleyman Nahifi Hayatı, Eserleri ve Hilyetü'lenvar'ı, Marmara Üniversitesi SBE, Basılmamış YL Tezi, İstanbul 1994; Oya Yasav, Hilyetü'l-Envar, Marmara Üniversitesi SBE, Basılmamış YL Tezi, İstanbul 1995; Yusuf Karaca, Süleyman Nahifi Efendi ve Mevlidi, Ankara Üniversitesi SBE, Basılmamış YL Tezi, Ankara 1997; Arife Çomar, Süleyman Nahifi, Enfüsü'l-Afak, Marmara Üniversitesi SBE, Basılmamıs YL Tezi, İstanbul 2001; 
Nahîfî’nin Münşeât' 'nın varlığından bizleri haberdar eden ilk kişi Ali Cânib Yöntem'dir. 1927 yılında Hayat Mecmuası'nda Nahîfî hakkında kaleme aldığı makalede, şairin diğer eserlerinden olduğu gibi Münşeât'ından da bahsetmiş; eserden alıntılar yaparak çeşitli değerlendirmelerde bulunmuştur. ${ }^{24}$

Abdülbaki Gölpınarlı, Varlık Yayınları için hazırladığı muhtasar Divan Şiiri (XVIII. Yüzyıl) adlı eserde Nahîfî' den bahsederken şairin Münşeât'ının olduğunu bildirir. ${ }^{25}$

1995 yılında Halil İbrahim Haksever tarafından hazırlanan Eski Türk Edebiyatında Münşeâtlar ve Nergisî'nin Münşeâtı adlı doktora tezinde, Nahîfî'nin Münşeât'ının mahiyeti hakkında bilgi verilmeksizin iki nüshasının olduğu bildirilmiş ve fazla bir değerlendirme yapılmamıştır. ${ }^{26}$

Diyanet Vakfi İslâm Ansiklopedisi'ne yazılan Nahîfî maddesinde, Münşeât'tan bahsedilmiş, ancak muhtevasına yönelik yapılan değerlendirme de Makâlât-ı Nahîfî ile karıştırılmıştır. ${ }^{27}$

Türk Edebiyatı İsimler Sözlüğ̈̈ için yazılan Nahîfî maddesinde ise eserin ismi zikredilmiş; mahiyeti hakkında değerlendirme yapılmamıştır. ${ }^{28}$

Bu makalenin tamamlandığı sırada Nahîfí Süleyman Efendi Külliyâtı adlı bir eserin yayınlandığı duyurulmuş; eserin tanıtımında Münşeât'ın da transkribe edildiği bilgisi verilmiştir. $^{29}$

Haşim Keskinsoy, Mekkî ve Nahifí'nin Kaside-i Bürde Tahmisleri, Kahramanmaraş Sütçü İmam Üniversitesi SBE, Basılmamış YL Tezi, Kahramanmaraş 2011. (Bu tezdeki Nahîfî hakkındaki bilgiler, Diyanet İslâm Ansiklopedisi'ndeki "Nahîfi" maddesinin tekrarıdır.)

${ }^{24}$ Ali Cânib Yöntem, “On İkinci Asr-1 Edebî’nin Meşhûr Sîmâlarından Süleymân Nahîfî”, Hayat Mecmuası, S. 22, s. 423-426, 28 Nisan 1927.

${ }^{25}$ Gölpınarl1, age., s. 11.

${ }^{26}$ Haksever, agt., s. 135.

${ }^{27}$ Uzun, age., s. 299. Bahsi geçen Makâlât-ı Nahîfî adlı eser incelenmiş ve bu metnin, A. Çelebioğlu tarafindan neşredilen Risâle-i Hizriyye'nin farklı bir nüshası olduğu tespit edilmiştir.

28 Karavelioğlu, agm, http://www.turkedebiyatiisimlersozlugu.com/index.php?sayfa=detay\&detay=2663 [erişim tarihi: 01.11.2014]

${ }^{29}$ Şaban Er, Nahîfî Süleymân Efendi Külliyâtı, Kutupyıldızı Yay. İstanbul 2014. Eserin temini için makale bekletilmiş; yayınlandığı bilgisi (27.11.2014) ilan edildikten 25 gün sonra kitap satışa sunulmuştur. Kitapta nüsha tanıtımı ve kısa bir değerlendirmeden sonra Münşeât'ın metni verilmiştir. Mektupların yazım tarihi ve muhatapları, muhteva, dil ve üslûp hususiyetleri ayrıntılı irdelenmemiştir. Bazı mektuplarda göz yanılması sebebiyle satır atlamaları, müstensihin dikkatsiz hattından kaynaklanan kısmî okuma hataları ve vezin problemleri bulunduğu için daha evvelden hazırladığımız bu makalenin neşredilmesine karar verilmiştir. 


\subsection{Nahîfî̀ Münşeât'ının Nüshaları:}

Kütüphane kayıtları ve kataloglarda yapılan aramalar neticesinde "Münşeât-1 Nahîfî" adıyla kaydedilmiş iki nüshaya ulaşılmıştır. Bunlardan ilki Millet Kütüphanesi Ali Emîrî Edebiyat 406 numarada kayıtlıdır. Tamamı 28 yaprak olan yazma, 206x145, 145x70 mm ölçülerindedir. Metnin satır sayısı şiirlerin bulunduğu kısımlarda değişmekle beraber umumiyetle 19'dur. Nesih hatla ve başlıklar kırmızı, diğer kısımlar siyah mürekkeple yazılmıştır.

Eserin zahriyesinde "Enderûn-1 Hümâyûn'a çıraklık için merhûm Câvid Ahmed Beg'e gönderilen arz-1 hâldir" başlığıyla kaydedilmiş bir mektup yer almaktadır. Asıl eser 1b'de başlar. Metnin üzerine "Meşhûr Süleymân Nahîfî'nindir" diye bir not düşülmüştür. Tamamı bir bütünmüş gibi yazılmış, bağlam gözönünde tutulduğunda birbirinden bağımsız sekiz mektuptan meydana gelen metin 26a'da sona ermektedir. Burada sayfa kenarına "Küçükoda'da Galatasarâyı'nda Hâricî-zâde ${ }^{30}$ merhûma tahrîr etdirmişimdir" ibaresi farklı bir hatla kaydedilmiştir. ${ }^{31}$ 26b-28a arasında ise Seyyid İbrâhîm isimli biri tarafından yazılmış yedi mektup yer almaktadır. 28b'de ise kime ait olduğu bilinmeyen bir mektup ve bu mektubun altında Alî Emîrî Efendi'ye ait vakıf mührü bulunmaktadır.

Yazmanın müstensihi çok dikkatli değildir. Eser boyunca birçok yazım hatası yapmıştır. Kimi zaman "hâ" ile yazılması gereken kelimeleri "hı" ile yazmış, "sin"ler ve "şın"ları, "be"ler ve "ye"leri karıştırmış, birçok yerde harfleri eksik yazmış, harflerin noktalarını koymayı unutmuştur.

"Münşeât-1 Nahîf̂” adıyla kayıtlı ikinci yazma ise İstanbul Büyükşehir Belediyesi Atatürk Kitaplığı'nda Muallim Cevdet Yazmaları 22 numarada bulunmaktadır. 240x185 mm. ölçülerinde, VII+98 varaktan müteşekkil bir yazmadır. Yazmanın zahriyesinde "Münşeât-1 Nahîfî Efendi" "Sene 1275(1858-59)" kayıtları vardır. 1b-40b arasında 156 kisa mektup/ariza bulunmaktadır. 156. arizanın altında "Harrerehû Tâhir Şevkî-i Belgradî, Sene 1281(1865)" kaydı vardır. 41a boş olup 41b-42a'da önceki kısımda yer alan 156 mektup/arizadan farklı olarak 3 mektup daha mevcuttur. 42b'den 92b'ye kadar olan kısım boştur. 92b-93a'da İbrahim İzzet Belgradî’den Bosna Vilayeti yetkililerine yazılmış 3 ariza vardır. 93b-97a arası boştur. 97a'da bir babadan oğluna derslerine iyi çalışması ve okuluna devam etmesi hususunda yazılmış kısa bir

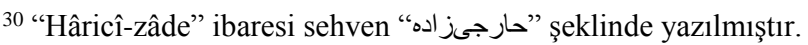

${ }^{31} \mathrm{Bu}$ ibareden hareketle Millet Kütüphanesi yetkilileri eserin Nahîfî tarafından yazdırılmış olabileceği sonucuna varmışlardır. Bizce bu sonuç kesinlikle yanlıştır. Nahîfî gibi âlim ve hattat bir şairin böylesi dikkatsiz bir müstensihe eser çoğalttırması ve sonuna kendi yazdığı bildirilen tek satırlık ibareyi bile yanlış/eksik yazması güç bir ihtimaldir.
} 
mektup bulunmaktadır. 97b boştur ve 98a'da Makâm-1 Ser-askerîye yazılmış bir müzekkere yer alır.

"Münşeât-1 Nahîfi”" adıyla kayıtlı ikinci yazma, aynı adla kayıtlı ilk yazmadan tamamıyla farklıdır. Süleyman Nahîfî’nin isminin yer almadığı, kime yazıldığı belli olmayan, edebî ifadelerden uzak, herhangi bir devlet işiyle alâkalı malumatın aktarıldığı tarihî belgelerdir. Eserin neye istinaden "Nahîfî"ye mâl edildiği ve bu Nahîfî’nin hangi Nahîfî [Şemseddin Nahîfî (ö. 1494), Ispartalı Mehmed Nahîfî (ö. 1610), Süleyman Nahîfî (ö. 1738), Keşanlı Mehmed Nahîfî (ö. 1788), Mustafa Nahîfî (ö. 1849)] olduğu tespit edilememiştir.

Ayrıca münşeât mecmualarında yapılan taramalarda, Kastamonu İl Halk Kütüphanesi 37 Hk 3753/1 numarada kayıtlı "Mecmua-i Münşeât ve Fevâid" adıyla kayıtlı içinde fetva örnekleri, silsilenâmeler, lugazlar ve bazı şairlerin mektup örneklerinin bulunduğu mecmuada Nahîfî’ye ait mektupların olduğu kayıtlıdır. ${ }^{32}$ Adı geçen eser üzerinde yapılan ayrıntılı incelemede Nahîfî’ye ait mektuba rastlanmamıştır.

\subsection{Mektupların Muhatapları:}

Münşeâtlarda, bilhassa Lâmi‘î, Nergisî ve Nâbî gibi klasik Türk edebiyatının önde gelen sîmâlarının kaleme aldıkları mektuplarda umumiyetle muhatapların ismi ve bazen de mektubun yazılma sebebi başlığa kaydedilmiştir. ${ }^{33}$ Nahîfî’nin Münşeât' 'nda ise böyle bir tasarrufta bulunulmamıştır. Mektupların kimlere yazıldığı sadece metin içindeki küçük ipuçları vasıtasıyla tespit edilebilmektedir. Muhatapların kim ya da kimler olabileceğine yönelik karinelere geçmeden Münşeât üzerinde çalışma yapanların bu konudaki fikirlerini değerlendirmek istiyoruz.

Nahîfî’nin Münşeât'ını inceleyen ilk araştırmacı olan Ali Cânib Yöntem mektupların muhatabına yönelik şu değerlendirmelerde bulunur:

"Yaşadığı aşk maceralarının günü gününe tesbît edilmiş ilhâmlarından

ibâretdir. Mektûblarının çoğu sevgilisinin vefâsını, ba'zısı lâkaydîsini anlatır.

Ekserîsi irticâlen yazılmış manzûmeleri ihtivâ eder."34

Şaban Er ise Ali Cânib'in yanıldığını ifade ederek bu mektupların bir devlet büyüğüne veya dostuna yazdığ 1 iştiyak mektupları olduğunu söyler:

\footnotetext{
$32 \mathrm{http} / / /$ www.yazmalar.gov.tr/detay_goster.php?k=50046

${ }^{33} \mathrm{Bu}$ konudaki örnekler için $b k$. Hüseyin Karaman (haz.), Lâmi ‘î Çelebi’nin Münşeâtı, Kocatepe Üniversitesi SBE, YL Tezi, Afyon 2001, s. 61, 73; Haksever, agt., 343, 349, 351.

${ }^{34}$ Yöntem, agm., s. 423.
} 
"Nahîfî Efendi'nin bu mektûblarındaki muhâtabı sevgilileri değildir ki aşklarından bahsetmiş olsun! Gerek Cânib'in birkaç paragrafını alarak bu garîp değerlendirmede bulunduğu beşinci ve altıncı mektûbların veyâ gerekse hị̧̂ bahs etmediği diğer 6 mektûbun tamâmı tedkîk edilirse, hakîkat anlaşılacaktır. Evet, Nahîfî Efendi’nin âşıkâne şiirleri de vardır ve dîvân nüshalarında kayıtlıdır; ancak bu mektûbları sevgililere yazılmış aşk mektûbları değil, zâhirî ve bâtınî makâmları pek yüksek bir devlet adamına veyâ bir dostuna iştiyâk mektûblarıdır." ${ }^{35}$

Bizce Ali Cânib Yöntem, aşk mektuplarından hareketle Nahîfî’nin mektuplarının tamamını aşk mektubu olarak değerlendirmiş; Şaban Er ise Nahîfî’nin dostlarına yazdığı 2, 6 ve 8. mektuplarından hareketle Münşeât'taki mektupların tamamının dostlara yazılmış olabileceği yönünde kanaatlerini bildirmiştir. Şüphesiz bu çıkarımda bulunmasında Nahîfî’nin Hz. Peygamber sevdalısı, âlim, fâzıl ve dindâr bir şahıs olması etkindir.

Münşeât ayrıntılı tedkîk edildiğinde mektupların muhataplarının iki gruba ayrıldığı görülecektir. İlk gruptaki mektupların muhatabı, şairin gönülden bağlı olduğu, âşık olduğu kişidir. İkinci gruptaki mektupların muhatab(lar)1 ise Nahîfî’nin dostlarından birileri olmalıdır. İlk gruptaki mektupların muhatabının kim olduğu hususunda yazar, Münşeât’ta şu ipuçlarını verir:

“Ḥattā bu șabāh -ki șabāḥu'l-ḩayr-1 yevmü'l-ḩamīsdür ve ibtidā-yı donanmayı nefīsdür- cünūd-1 țuyūrdan ḳamārī du ācılarına vazịife-i faḳīāne olan erzenefşānde-i dest-i i' tiyād olurken, mürüvvetlü efendimüñ teveccüh ü rag̉beti dil ü cāna galebe idüp, neşr ü nișār üzre iderken 'Arabī ve Fārisī edā ile ba' de'lbesmele “' alā yedi Feyżu'llāh, be-dest-i pāk-i Feyżu’llāh” diyü ḳumrucuḳlara erzen-efşān-1 emānet-i du'ā oldum. Hiç bunı yazmak şīve-i cünūndan aşag̉ı degildür, ammā efendim galeyān-1 'aşk ādemi böyle hayret-zede vü hallạt eyler." (vr. 4b)

"Benim efendim, cünd-i ḳamārī her seherer 'alā yedi Feyżu'llāh 'unvānıla erzen-efşān olup efendime lisān-1 ḥāl tesbịhüñiz siyāḳında du' ā-yı ḩayr eyleñ diyü, Mecnūn-1 ‘Ādīye şebīh ḩālet ẓuhūr ider oldı.” (vr. 15b)

1. ve 4. mektuplarda yazar, mektubunun muhatabının ismini "Feyzullah" olarak bildirir. 3, 5 ve 7. mektuplarda muhatap olarak herhangi bir şahsın ismi anılmaz. Ancak 1 ve 4. mektuplardaki lirik ifadeler, hitap tarzı ve âşıâne üslûp diğer mektupların da "Feyzullah"a

\footnotetext{
${ }^{35}$ Er, age., s. 193.
} 
yazılmış izlenimini uyandırır. Bu mektuplardaki sevgi ve muhabbet ifadelerine 2,6 ve 8 . mektuplarda hiç rastlanmaz, sıraları bildirilen bu mektuplar muhtemelen dostlarından birilerine yazılmıştır.

Mirzâzâde Sâlim Efendi, tezkiresinde Nahîfí'den bahsederken onunla alâkalı şöyle bir latifeye yer vererek bir mahbûba âşık olduğunu bildirir:

"Latîfe: Eyyâm-1 güzeştesinde mütercem-i pâkîze-ta'bîr bir nev-cevân-1 servkâmetin kemend-i zülf ü dâm-1 sevdâsina giriftâr ü esîr oldugu demler bâr-1 tâkat-güzâr-1 'işve vü nâzdan esîr-i firâş olup dil-hûn ve pister-i derd ü mihnetde zâr u zebûn olmagın ber-kâ'ide haste ve zahm-1 bî-'ilâc-1 'aşk ile şikeste yatır iken dil-dâdesi oldugu yâr-i nâzik-zâmîr bunun hâste vü derdnâk oldugundan habîr olup ol zâr u bî-çâreyi 'iyâdet ve hasteligin görmege gelip ziyâret eylediginde dest-i sîmînin ol dil-şudenin sîne-i gamgînine koyup bîçârenin hâl ü hâtırın su'âl eyledikde yatdıgı yerden derdmend bu hasb-i hâl ile bed'en makâl eyledigi mütercem-i sâf-bâlin şayeste-i merhamet olduguna istidlâl olunur.

Beyt

Sanma rahminde sunar destin dil-i mecrûhuma

Ol kemân-ebrû cigerde tîr-i müjgânın $\operatorname{arar}^{36}{ }^{37}$

Sâlim Efendi'nin beyan ettiği üzere Nahîfî’nin âşık olduğu kişi bir mahbûbdur. Mektuplarda ismi verilen Feyzullah, bir erkek ismidir. Samimî ve âşıkane hislerle yazılmış zarif ifadelerin muhatabı Feyzullah, Sâlim Efendi'nin bahsettiği mahbûb olabilir. Bu ihtimali güçlendiren yegâne delil ise Feyzullah'a yazılan mektupların, Sâlim Efendi'nin Tezkiretü'şŞu 'arâ'sının tamamlanmasından evvel kaleme alınmış olmasıdır. ${ }^{38}$

Her ne kadar bugünün insanının tasavvuruna uygun olmasa da klasik Türk edebiyatı dönemi şairlerinin birçoğunun ve bazı mutasavvıf şahsiyetlerin divanlarında mahbûbların isimlerine yer verildiğine, onlara âşık olunduğuna dair ibare ve ifadelere rastlanmaktadır. Divan şiirindeki bu tasarruflar farklı açılardan izah edilmektedir. "Gerek aynı cinsten gerekse karşı cinsten bir insanı sevmek tabiî aşktır. Meşrû sınırlar içinde kalması şartıyla tabiî aşk mübah ve

\footnotetext{
${ }^{36} \mathrm{Bu}$ şiirin tamamı için $b k$. Aypay, age., C. II, s. 123.

${ }^{37}$ İnce, age., s. 657-58.

38 İleride de görüleceği üzere Feyzullah'a gönderilen mektupların yazım tarihi 1125/1713-14'tür. Sâlim Efendi'nin Tezkiretü'ş-Şu 'arâ'sının tamamlanış tarihi ise 1134/1722'dir. bk. Haluk İpekten, vd., Şair Tezkireleri, Grafiker Yay., Ankara 2002, s. 109.
} 
câizdir." ${ }^{39}$ Ayrıca erkek güzelliğine hayran olma duygusu mutlaka cinsî arzular uyandırmaz. Her şeyden evvel güzellik insanda olsun, tabiatta veya eşyada olsun başı başına bir değerdir. Dinî duygu, örf ve âdetlerin sıkı baskısı altında yaşayan ve ince bir zevke sahip olan, tasavvuf ile beslenen bu şairlerin hepsini, şehevî hislerinin esiri kabul etmek yanlıştır. ${ }^{40}$ Klasik Türk şiirinde aşkın niceliğiyle alâkalı araştırmalarda ortaya konduğu üzere ilâhî aşk, en kudretli tecellisini güzel insan çehresinde kendini gösterir. Âşı̆̆ın, maşûka bakışı temiz olmalı ve her türlü çirkin ihtiraslardan uzak bulunmalıdır. Hem mahbûbun hem de mahbûbenin böyle bir hisle temaşası, insanı İlâhî aşka ulaştırır ve hakka vasıl eder. ${ }^{41}$ Özellikle bazı mutasavvıf ve dindar şairler, güzellerin suretlerini İlâhî güzelliği aksettiren bir ayna gibi kabul etmekte; onların varlıklarında, yüzlerinde Allah'ın çeşitli isim ve sıfatlarının tecellisini seyrettiklerini anlatmaktadırlar. Buna benzer alâka ve aşk ifadelerinde şehevî bir niyet ve nazar sezilmemekte; cemâl sahibi yaratıcının güzelliğinin insan ve tabiattaki tezahürlerine karşı hayranlığın söz konusu olduğu görülmektedir. ${ }^{42}$

Hayatı boyunca dinî ve nasihat-âmiz eserler kaleme almaya gayret eden; bilhassa $H z$. Peygamber'e duyduğu muhabbet ve hasretin neticesinde birçok na't, mevlid, hilye $v b$. türlerde şiirler kaleme alan; Mevlânâ'nın Mesnevî'sini manzum olarak Türkçeye çeviren ve bazı kaynaklarda Mevlevî olduğu bildirilen Nahîfî’nin Feyzullah isimli kişiye karşı aşkı, dindar ve mutasavvıf şairlerin bütün güzel ve güzelliklere yönelik aşkları kategorisinde değerlendirilmelidir. Nahîfî'nin adı geçen şahsa dinî ve ahlâkî sınırların dışında davrandığını iddia etmenin şaire yapılacak bir haksızlık olacağı kanaatindeyiz. Zira mektuplarda da görüldüğü üzere şairin âşık olduğu kişiye yönelik gayr-1 meşrû münasebeti aksettirecek hiç bir ifadesi bulunmamaktadır. Aksine Nahîfî, muhatabına dinî telkinler ve nasihatlarda bulunur:

- "Eger taḳdīr-i Hلjallāḳ-1 Bī-çūn ile ḥasret ü iştiyāḳına taḥammül idemeyüp ölürsem, cān-1 nālānımı ve rūḥ-1 revānımı Fātiḥa ve İhlāṣ ve du ā-yı ḩayr ile mesrūr ve der-yād eylemeñi niyāz iderim. Eger mevt muḳadder ise mev` id-i mülāḳātımız, civār-1 sulțān-1 enbiyāda - 'aleyhi efḍalü’t-tehāyā- ve firdevs-i a' lāda olmaḳ recāsın eylerim.” (vr. 6a)

\footnotetext{
${ }^{39}$ Süleyman Uludağ, Tasavvuf Terimleri Sözlüğü, Marifet Yay., İstanbul 1997, s. 61.

${ }^{40}$ Mehmet Kaplan, "Divan Şiirinde Kadın Aşkı Yok mudur?", Osmanlı Divan Şiiri Üzerine Metinler, haz. Mehmet Kalpaklı, Yapı Kredi Yay., İstanbul 1999, s. 263.

${ }^{41}$ Agâh Sirrı Levend, Divan Edebiyatı, Enderun Kitabevi, İstanbul 1984, s. 589-90.

42 Âdem Ceyhan, "Ahmed Paşa'ya Bir İsnad Dolayısıyla Divan Şiirinde Aşkın Niceliği”, Bursalı Şair Ahmed Paşa ve Dönemi, Editör: Bilal Kemikli, Bursa 2010, s. 270.
} 
- "Çoḳ çok șalavāt-1 şerīfeye meşgìūl ol, seni Allāhu 'azīmü'ş-şāna ḥavāle eyledim. Ben ḳuluñı efendim du' ā-yı ḩayrdan ferāmūş eyleme. ” (vr. 8a)

- "Ben el-ḥamdüli'llāhi te ālā İslāmı ve 'ırżımı anuñ gibi mi bilürüm? Yā senüñ ' 'rżuñı, dīnüñi ve sā’ir umūruñı benim gibi mi șaḳınur?’ (vr. 24b)

- "İlā āyā ne țarīk ile ḳudretim mertebesi maẓhar oldıg̉ım nicam-1 celīle-i İlāhiyye'yi, efendime vāris ideyim diyü, mülāḥaẓa eșnāsında ḳaț ā görmeyüp ve işidmedigim nesaḳ üzere emșile-i 'Arabiyye’ye tațiḳ ile ba' $̇$ ż-1 ḳavā'id-i Fārisiyye beyān itmek bābında, bir nümūne ve bend ihtirā' olunmışdur ki şāyeste-i naz̧ar-1 rag̉bet ü i` tibārları olursa dahi a' lāsı mümkindür.” (vr. 14a)

Bunlara ilaveten mektuplarda birçok Arapça dua, temenni ve âyetlerden örnekler vardır. Kişinin gayr-1 meşrû münasebet tesis ettiği birine, hem dinî telkînde bulunması hem de sözlerini dua ve âyet iktibaslarıly desteklemesi mümkün görünmemektedir.

\subsection{Mektupların Yazım Tarihi:}

Metnin içinde mektupların yazım tarihine dair herhangi bir kayıt bulunmamaktadır. Farklı zamanlarda yazılmış intibaını uyandıran mektupların tamamının yazım tarihlerini tespit etmek güçtür. Ancak Münşeât'taki bazı ifadeler, mektupların yazım tarihiyle alâkalı ipuçları vermektedir. Yazar 2. mektubunda, muhatabının kendisinden istediği Hilyetü'l-Envâr adlı eserinin henüz bitmediğini beyan eder; müsvedde olduğunu söyleyerek bazı kısımlarının da tamamlanmadı̆̆ını ifade eder:

"Ba' dezāa Hilye-i Şerīfe-i Șaḥịha murād buyurulmış. 'Ale'r-re'si ve'l-' ayn!

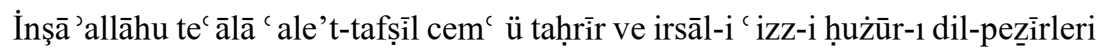
ḳılınur ve Hilyetü'l-Envār ismiyle müsemmā şerḥ-i manẓūme-i fakīīāne, periş̧ān-taḥrīi ü ebb-zede (?) ve ekṣer mevāżi i maḥv u iṣbāt ve tebdīl ü taḥvīle muḥtāc olmag̉la bir vech ile şāfiye-i naẓar ü irsāl degildür. Huudā ḥaḳḳıçün cān dirīg olmadığı muḥtāc-1 beyān degildür.” (vr. 9a)

"S̄âlișen muharrer olan dahi nā-tamām olup, beş altı cüz' ve hitāmında olan Ümmü Ma' bed rivāyeti gayr-1 mektūbedür. Yohssa va'llāhu' l- aẓim hilāf-1 riżā işāretlerine ' adem-i imtișāl emr-i muhạal idi. Bu mežkūrāt ma' lūm-1 sa ādetleri oldıḳdan șoñra, elbette buyrulur ise yine dirīg olunmaz. Ancak ketb ü istinsāḥ olunmamaḳ ve itdirilmemek şarṭyla meşrūṭ olursa luṭf idüp, huș̄uṣ̣-1 mezbūrda müsāmaḥamız bì-vefāyī vü nādānlı̀̇ımıza ḥaml buyurulmaya" (vr. 9a-9b). 
Hilyetü'l-Envâr, Nahîfî’nin $H z$. Peygamber'in fizikî özelliklerini anlattığı telifidir. Mesnevi nazım şekliyle kaleme alınan bu hilye, edebiyat tarihimizde yazılmış en hacimli hilyelerden biridir. Eserin sonunda şair, metnin tamamlanışına şöyle bir tarih düşürmüştür:

\section{Söyledi tārīhinini Rūḥu'l-Emīn}

"Ḥilye-i zỉbende-i fahrr-1 güzīin" $(1099)^{43}$

$\mathrm{Bu}$ beyte göre eserin tamamlanış tarihi 1099/1687-88'dir. Yazar, 2. mektubunda Hilyetü'lEnvâr'1 henüz bitirmediğini bildirdiğine göre, bu mektubun yazım tarihi en geç 1099/1687-88 olmalidir.

2. mektup ile 6. mektup arasında çeşitli yönlerden benzerlik bulunmaktadır. Her iki mektupta da Nahîfi, muhatabına eserlerinden bahsetmekte ve henüz tamamlanmadığını ifade etmektedir. Ayrıca muhatabının kendisinden istediği eserlerini göndermektedir.

“'Ba' dezāā Hilye-i Şerīfe-i Șahihha murād buyurulmış. 'Ale'r-re'si ve'l-' ayn!

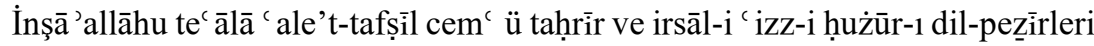
ḳ1lınur ve Hilyetü'l-Envār ismiyle müsemmā şerh-i manẓume-i faḳirāne, perişāan-taḥrīi ü ebb-zede (?) ve ekșer mevāżi i mạ̣v u iṣbāt ve tebdīl ü taḥvīle muhtāc olmag̉la bir vech ile şāfiye-i naẓar ü irsāl degildür. Huudā ḥaḳḳçün cān dirīig olmadığ́ muḥtāc-1 beyān degildür.” (vr. 9a)

“Bānet $S u^{\prime} \bar{a} d$ Kașìdesi Tahmisisi'nden șoñra ḥālā muḥarrer olan maḥalle dek beyāż kāg̀ıdlar ḳonulmışdur. Maḳṣūd Türkī ve Fārisī taḩmīsleri taḥrīr idüp, 'afvları mercūdur ve ġazel-i mežkūr geregi gibi tafșīl ve tersīl olsa gerek idi. Ancaḳ bir vech ile ruhṣat-1 zamān olmadı. Luṭf idüp, her ne ḳadar ḳuṣūrum var ise 'afv buyrula." (vr. 19b)

Nahîfî’ nin, Ka‘b bin Züheyr’ in (ö. 645) Kasîde-i Bürde ve Bânet Su 'âd isimleriyle bilinen meşhur şiirine Türkçe tahmis yazdığı bilinmektedir. Ancak yukarıda da bildirildiği üzere şair, yazdığı tahmise ilaveten Türkçe ve Farsça tahmisler yazmayı da düşündüğünü beyan etmektedir. $\mathrm{Bu}$ durumda Nahîfi’’nin yazdığını söylediği tahmis, İmâm Busîrî’nin (ö. 1296) Kasîde-i Bürde'sinin Arapça tahmisi olmalıdır. Çünkü şair, sadece İmâm Busîrî’nin Kasîde-i Bürde'sine Arapça, Farsça ve Türkçe tahmisler yazmıştır. Bahsi geçen Arapça tahmisin günümüze ulaşmış bir yazma nüshası yoktur. Kütüphanelerimizde birçok yazma nüshası bulunan Türkçe tahmisin ise yazım tarihi kesin olarak belli değildir. Ancak eserin en eski yazma nüshalarının istinsah tarihi

\footnotetext{
43 "Hemze" "1" kabul edildiğinde sonuç tam çıkar. Mehtap Erdoğan (haz.), Türk Edebiyatında Manzum Hilyeler, Cumhuriyet Üniversitesi SBE, Dr. Tezi, Sivas 2011, s. 984.
} 
1114/1702-03 y1lına aittir. ${ }^{44}$ Bu kayıt bizlere İmâm Busîrî’nin Kasîde-i Bürde'sine, Nahîfî’nin yazdığı Türkçe tahmisin en geç 1114'te kaleme alınmış olabileceğini gösterir. 6. mektubunda Nahîfî, (Arapça) Kasîde-i Bürde Tahmisi'ni henüz bitirdiğini, Türkçe ve Farsça tahmisler de yazmayı düşündüğünü belirttiğine göre; 6. mektubun en geç yazılma zamanı, Kasîde-i Bürde'nin Türkçe tahmisinin yazılışından önce olmalıdır. Bir başka deyişle, Kasîde-i Bürde'nin Türkçe tahmisinin tespit edilen istinsah tarihi, 6. mektubun, 1114/1702-03'te veya bu y1ldan önce kaleme alındığ ispatlar.

4. mektupta yer alan tarih beyti bu mektubun yazım tarihi hakkında bizlere önemli ipuçları sunar. Yazar, muhatabına tamiyeli bir tarih yazdığını; eğer uygun görülürse mülahaza edilmesini ister:

“...Mecnūn-1 'Ādìye şebīh hāalet zuhūr ider oldı. Encāmı hayr ola benim efendim.

Dü destim ref ${ }^{r}$ idüp dergāh-1 Ḥaḳka söyledim tārīh

Mu'ammer eylesin Şeh-zāde 'Abdü'l-Mālik'i Mevlā

diyü "iki”" ziyāde ta miyeli tāriḩ inşād olundı. Efendime münāsib ise mülāḥaẓa

buyurasız ..." (vr. 15b-16a)

Düşürülen tarihin sayı değeri 1123'tür. Tarihin tamiyeli olduğunu bildiren yazar, çıan sonuca "dü destim ref" idüp" diyerek "iki" ilave edilmesi gerektiğini ilk misrada bildirmiştir. Böylelikle düşürülen tarihin sayı değeri 1125 olur, miladî 1713-14 yılına tekabül eder. Bu sonuç 4. mektubun en erken 1125/1713-14 y1lında yazılmış olabileceğini gösterir. 4. mektubun muhatabı, şairin mahbûbu Feyzullah olduğuna göre; Feyzullah'a yazıldığını tahmin ettiğimiz diğer mektuplar da (1, 3, 5 ve 7 . mektup) bu tarihe yakın zamanlarda kaleme alınmış olmalıdır. Zira mektuplar arasında bazı ifadelerde kısmî benzerlikler bulunmaktadır:

“Ḥattā bu șabāḥ -ki șabāḥu'l-ḩayr-1 yevmü'l-ḩamīsdür ve ibtidā-yı donanmayı nefīsdür- cünūd-1 țuyūrdan ḳamārī du ācılarına vaẓife-i faḳīāne olan erzenefşānde-i dest-i ic tiyād olurken, mürüvvetlü efendimüñ teveccüh ü raġbeti dil ü cāna galebe idüp, neşr ü nisāa üzre iderken 'Arabī ve Fārisī edā ile ba' de'lbesmele “‘ alā yedi Feyżu'llāh, be-dest-i pāk-i Feyżu'llāh” diyü ḳumrucuḳlara erzen-efşān-1 emānet-i du' ā oldum. (vr. 4b)

\footnotetext{
${ }^{44}$ http://yazmalar.gov.tr/detay_goster.php?k=105551; http://yazmalar.gov.tr/detay_goster.php?k=129982
} 
"Benim efendim, cünd-i ḳamārī her seḥer 'alā yedi Feyżu'llāh 'unvānıyla erzen-efşān olup efendime lisān-1 hāal tesbihhüñiz siyāḳında du' ā-yı hyayr eyleñ diyü, Mecnūn-1 ‘Ādīye şebīh ḩālet ẓuhūr ider old..” (vr. 15b)

Nahîfî'nin toplam sekiz mektubundan, üçünün (2, 4 ve 6 . mektuplar) çeşitli karineler vasıtasıyla tahmini yazılış zamanları ortaya konmaya çalışılımış; dördünün de $(1,3,5$ ve 7 . mektuplar) muhtemel yazım tarihleri üzerinde durulmuştur. Münşeât içindeki son mektubun yazım tarihi hakkında her hangi bir çıkarımda bulunulamamıştır.

\subsection{Mektupların Muhtevası:}

\section{Mektup:}

Nahîfî, mektubuna esmâü'l-hüsnâdan seçtiği Allahu teâlânın isimlerinden bazılarını zikrederek başlamıştır. Hemen hemen birçok münşeâtta benzer şekillerde yer alan kalıplaşmış giriş cümlelerini, muhatabına uygun şekilde düzenleyerek uzun bir giriş yapmıştır.

Bir mektup için uzun kabul edilebilecek şekilde yazdığı hamdele ve salvelenin ardından yazar, mektubunu kaleme alma sebebine değinir. Muhatabına duyduğu muhabbet ve hasretin neticesinde elinde olmaksızın yazmaya başladığını beyan eder. Asıl konuya bundan sonra girer ve muhatabına vasiyet olarak çeşitli nasihatlar eder. Kendisini unutmamasını, en azından yazdıklarına cevap vererek kendisini mutlu etmesini diler. Mektubun uzun girişine muvafık bir hâtimeyle (çeşitli dualar ve temennilerle) söyleyeceklerini tamamlar.

\section{Mektup:}

Birinci mektuba nazaran farklı bir girişin yapıldığı bu mektupta yazar önce muhatabına dua eder. Ardından hemen asıl konuya girer. Kendisinin Hilyetü'l-Envâr adlı eserini talep eden muhatabına, eserinin henüz temize çekilmediğini, çeşitli tashihlere muhtaç olduğunu bildirir. İstinsah edilmemek kaydıyla gönderebileceğini söyler. Muhtemelen daha evvelki görüşmelerinde ya da yazışmalarında kendisine anlatılan rüyayı tabire başlar. Tabiri tamamladıktan sonra yazdığ 1 kâğıdın kötü olmasından ve acele yazdığından dolayı özür dileyerek mektubunu tamamlar.

\section{Mektup:}

İlk mektuba nazaran daha kısa olan bu mektupta, kalıplaşmış giriş cümleleri bulunmamaktadır. Bunun yerine yazarın, muhatabına yönelik temenni ve dualarının yer aldığı uzun bir kısımla başlanmıştır. Muhatap, Nahîfî’ye gönderdiği mektubunda bir sebepten ötürü önce üzüldüğünü, daha sonra Nahîfî’nin memnuniyeti öğrenince teselli bulduğunu bildirmiş̧; 
bunun üzerine Nahîfî de karşısındakini çeşitli dualarla tazim etmiştir. Nahîfî, muhatabının mektubu kendisine ulaşmadan birkaç gün evvel rüyasında muhatabını gördüğünü, sohbet ettiklerini belirtmiştir. Ayrıca yazar bu mektubunda bir müfred ve on yedi beyitlik bir kıtaya yer vererek muhatabına olan sevgi ve hasretini; onunla alâkalı dua ve temennilerini şiirleriyle anlatmıştır.

\section{Mektup:}

Arapça bir salveleyle başlayan 4. mektubun girişinde, muhatabı selamlayan bir müfred yer almaktadır. Kalıplaşmış giriş cümlelerinin ardından yazar, sevdiğine arz-1 hâlini ifade etmeye bir beyitle başlar. Arapça ve Farsça konusunda bildiklerini muhatabına nasıl öğretebileceği hususunda düşünürken örnek olarak aklına birşeyler geldiği, bunları yazıp gönderdiğini; eğer beğenilirse daha iyilerinin kaleme alınabileceğini söyler. Ayrıca Nahîfî, sahip olduğu ilim ve irfanı kısa sürede muhatabına nasıl aktarabileceği konusunda elinden birşey gelmediğini söyler. Kendisine bu derece ince ve zarif manaları anlama kabiliyetini ihsan eden Allah'1n, muhatabına en kısa zamanda sonsuz ilim ve maarif lutf edebileceğini beyan ederek çeşitli dualar eder. Bunlara ilaveten Nahîfî, divanında yer almayan birkaç şiirinden örnekler sunar. ${ }^{45}$ Hangi münasebetle yazıldığı bilinmeyen bir tane tamiyeli tarih düşürür. Arapça bir temenniyle mektubunu tamamlar.

\section{Mektup:}

Nahîfî tıpk1 4. mektubunda olduğu gibi, bu mektubunda da Arapça bir hamdelenin ardından sevdiğini manzum şekilde selamlar. Temenni ve dualarda bulunduktan sonra merâmını anlatmaya başlar. Muhatabının kendisine gönderdiği mektubun ulaşmasıyla yaşadığı duygulara değindikten sonra, muhatabının babası tarafından davet edildiğini söyler. Hem muhatabı hem de onun babası için çokça dualar ettiğini söyleyen yazar, elinde olmaksızın mektubunu kaleme almaya başladığını bildirir. Kim olduklarını tespit edemediğimiz Selim Ağa, Evliya Efendi ve Sır Kâtibi biraderi Mehmed Bey’den mektuplar aldığını; henüz bunlardan ilkini cevaplandırabildiğini söyler. 3’ü müfred, 1’i iki beyitlik dört şiiri mektubuna derceden yazar, şiirlerin henüz tamamlanmadığı için bu hâliyle gönderildiğini ifade eder. Muhatabından bu mektubu, gizli bir yerde okumasını; eğer mümkün değilse hemen yakmasını ister. Sevdiğinin dolaptan bir şey çıkarırken elini incittiğini öğrendiğini, bu yüzden duyduğu üzüntüyü bildirir. Diğer mektuplarında

${ }^{45}$ Münșeâtta yer alan șiirlerin hiçbiri, Nahîfî Dîvânı'nın tenkitli metninde bulunmamaktadır. bk. Ali İrfan Aypay, Nahifí Süleyman Efendi (Hayatı, Eserleri, Edebî Kişiliği ve Divanının Tenkitli Metni), Selçuk Üni. SBE, Basılmamış Doktora Tezi, Konya 1992. 
da olduğu gibi mektubunu acele yazdığını, tam olarak hâlini arz edemediğini söyler; yazısının kötü olmasından dolayı özür diler. Temenni ve dualarla mektup tamamlanır.

\section{Mektup:}

Mektup, muhatabın selamlanmasıyla başlar ve kısa bir dua-temenniden sonra asıl konuya girilir. Bu mektup, Nahîfî'ye gelen bir mektubun cevabı mahiyetindedir. Muhatap, yazardan (şiirlerinin kayıtlı olduğu) bir mecmuayı talep etmiş, Nahîfî de göndermiştir. Tıpkı diğer mektuplarda olduğu gibi çeşitli sebeplerden ötürü imlaya dikkat edemediğini söyleyen yazar özür diler. Nahîfî, İmâm Busîrî'nin Bânet Suâd Kasidesi'ne tahmis yazdığını, bu şiire Türkçe ve Farsça tahmis yazmak istediğini; bundan dolayı daha evvel aralarında bahsi geçen gazeli ayrıntılı kaleme alamadığı için mazur görülmeyi diler. Ayrıca bahsi geçen mecmuaya yazılmayan şiirleri de (1 müfred, 23 beyitlik bir hamamnâme, 13 beyitlik bir gazel) mektubuna ilave ederek gönderir. Mektup, şiirlerin bitişinden sonra kısa bir duayla tamamlanır.

\section{Mektup:}

Allah'ın kudretinin yüceliğini bildiren Arapça bir hamdeleyle başlar. Bunu takip eden ilki hasret ifadeleriyle yüklü, ikincisi dua ve selam sözcükleriyle dolu iki müfred yer alır. 1, 2 ve 4. mektuplardaki gibi samimi hislerle yazılmış giriş cümlelerinin ardından dua ve temennilerde bulunan Nahîfî asıl konuya girer. Sevgilisini görememekten dolayı, sitemli bir şekilde üzgün olduğunu beyan eder. Ancak görüşememelerinin sebebini öğrenince muhatabına bağl1lığının daha arttığını bildirir. Ara sıra kendisine mektuplar yazarak memnun edilmeyi beklediğini söyler. Görüşmelerine mâni olmak isteyen birinin olduğunu, muhatabının o kişiye verdiği cevaptan ötürü sevincini dile getirir. Bahsi geçen kişiyi çeşitli yönlerden tenkit eder. Muhabbet ve hasret ifadelerini tekrardan ifade ettikten sonra kısa bir dua ve Farsça bir müfredle mektubuna son verir.

\section{Mektup:}

8. mektup diğer mektuplardan farklı bir mahiyete sahiptir. Kalıplaşmış giriş cümleleriyle başlayan mektupta, Nahîfî sanat kaygısı güderek ${ }^{46}$ Arapça gramer kaidesi, aruz kalıbı, tıp, kelâm ve astronomi ilmi terimleri, fikıh usûlü terimleri, ateşle ilgili kelimeler ve bir evin bölümleriyle alâkalı terimler kullanmıştır. Giriş cümlelerine benzeyen ifadelerle mektubunu tamamlamıştır.

\footnotetext{
${ }^{46}$ Edebiyatımızda hüner göstermek maksadıyla noktasız harflerle belli bir konunun, tersane, dil bilgisi, müzik terimleriyle; kuş, meyve, çiçek adlarıyla; müstezatlı ifadelerle yazılmış birçok mektup mevcuttur. $b k$. Orhan Şâik Gökyay, "Tanzimat Dönemine Değin Mektup”, Türk Dili Dergisi Mektup Özel Sayıs1, 1974, S. 274, s. 20.
} 


\subsection{Münşeât'ın Dil ve Üslûp Özellikleri:}

Münşeâtlarda genel olarak kullanılan dil, klasik Türk nesrinin süslü nesir grubuna girer. Arapça-Farsça ifadelerin sıklıkla yer aldığı, yine bu iki dile ait kelime ve uzun tamlamaların yoğun olarak kullanıldığı bu gruptaki eserler, merâmın sanatlı bir şekilde anlatılmasının yanında yazarlarının güçlü birer münşî olduğunu göstermesi bakımından öneme hâizdirler. Münşeâtlarda kullanılan dil, muhatabın sosyal statüsüne göre değişiklikler göstermektedir. Devlet kademelerinde yüksek bir memuriyete sahip mektup yazarı muhatabı da kendi mevkiinde veya daha üst mertebelerde olduğunda inşâ ilmindeki kudretini göstermek amacıyla tumturaklı anlatım, süslü bir üslûp ve ağdalı bir dil kullanabilir. ${ }^{47}$

Nahîfî'nin Münşeât'nda kullanılan dil, şairin seleflerinin (Veysî, Nergisî, Nâbî vb.) aksine uzun Arapça, Farsça tamlamalardan ârî, tam olmasa da konuşma diline yakın bir dil kullanılmıştır. Şüphesiz bunda en önemli etkenler, muhatabın kimliği ve Nahîfî'nin başta Dîvân'1 olmak üzere diğer eserlerinde de görülen ağdalı anlatımdan uzak bir tavrı benimsemiş olmasıdır. Şair, muhatabına duyduğu muhabbetin tesiriyle hissiyâtını sadeye yakın bir dille âşıâne ve zarif bir üslûpla dile getirmiştir:

"Benim ' ināyetlü, ḥakịḳatlü, muḥabbetlü, diyānetlü, șadāḳatlü efendim, bolay ki birḳaç gün dahi te 'ḩir buyurulmag̉a himmet ve teveccühleri niyāz olunur. Nā-çār teşrīf-i ric' at lāzım gelürse bu 'abd-i müştāḳa ḳalem-i mübārekleri ile iki üç kelime olsun, ḥırz-ı bāzū-yı müfāharet olan nemiḳa-i dil-nüvāzları bīdirīì buyrula ki āhir-i ömrüme dek ḥırz-1 cān ve nāme-i emān ideyim.

Āh efendim, ḳaț ${ }^{\dagger}-1$ niyāz-nāme ideyim didikce, derd-i derūnum beni taḥrīk idüp, efendimüñ tașdí‘ ine cesāretden dest-keşìde olmag̉a ruhșat bulamam. Benim efendim hemān ḥıfẓ-1 İlāhīde olup, ș̣ḥ̣at u selāmet ve devlet ü sa ādet ile dā 'im ü bāḳi olasin. Her ḳime münāsib ise selām-1 fākịiānemiz iblāğ[1] emri fermānuña menūṭdur." (vr. 8a-8b)

“... dolābdan şey çıḳarurken bir mismār-1 küstāh̆ mübārek dest-i şerīfüñüzi āzürde eylemiş. Āh n'olaydı o mismār, benim sīneme zaḩm açup, efendime zerre ḳadar āzār u keder virmeye idi. İnşāàallāhu te âlā ref ${ }^{\mathrm{r}}$-i derecāta işāretdür." (vr. 18b)

\footnotetext{
${ }^{47} \mathrm{Bu}$ tür mektuplara örnek için $b k$. Halil İbrahim Haksever, "Veysî ve Nergisî’nin Karsılıklı Mektupları” Afyon Kocatepe Üniversitesi Sosyal Bilimler Dergisi 2, s. 2 (2001): 179-184; Halil İbrahim Haksever, "Nâbî Münşeâtında Mizahi İfadeler ve Râmî Paşa'ya Yazdığı Mizahi Mektup”, Turkish Studies, Volume 6/2 Spring 2011, p. 33-38.
} 
Merâmını anlatırken çoğunlukla âyet, hadîs ve kelâm-1 kibârlar vasıtasıyla anlatımını pekiştirme yoluna gitmiştir:

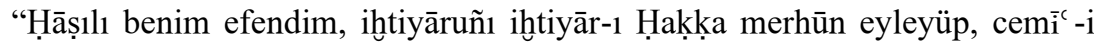
umūruñı ol Rabb-i Ḳadīre tefviż ve tevekkül-i tāmm ve șidk u ihlāṣ ile ẓuhūrāta 'adem-i ta' rīż üzere olmag̉a ziyāde iḳdām eyle. "سلم الامر للقضاء تسترح" mażmūnıyla ‘ amel eyle. Mevlā-yı Müte` āl ḳullarına cümleden erḥam ve zāhir ü bāṭın hāline ac lemdür. ${ }^{49}$ فتوكلنا على الله الكريم " (vr. 5b-6a)

Nesirle duygularını ifade etmekte yetersiz kaldığını düşündüğü durumlarda, şiire müracaat ederek (bilhassa muhatabın selamlandığı ve ona duyulan aşkın ifade edildiği kısımlara yazılan şiirler) anlatımına ayrı bir ahenk katmıştır:

“Dil-dāra șabā var yüri teblīig-i peyām it

Benden o şeh-i ḥüsne hulūṣ üzre selām it

Ahlāḳ-1 hamīde ve evșāf-1 pesendīdesine şāyeste ta' bīr-i belīg ile 'arż-1 'ubūdiyyet ü iştiyāḳda ḳāṣır oldığım muhabbetlü, ḥaḳiḳatlü, ṣadāḳatlü, mürüvvetlü efendim.” (vr. 16b)

“Āh benim muhabbetlü, ' ināyetlü efendim! Ne lisān ü lügat ve ne ta' bīi ü ' ibārāt ile 'arż-1 hulūṣ-1 muhabbet ve beyān-1 şürūṭ-1 'ubūdiyyet idecegim bilmem.

\section{Beyt}

Nice hâal-i dilimi eyleyem i` lām saña

Meger Allāh ide aḥvālimi ilhām saña” (vr. 2b)

Nahîfî Münşeât'ındaki dualarının bir kısmı Arapça olmasının yanında büyük çoğunluğu Türkçedir. Nahîfî mektuplarında klasik Türk nesrinin en önemli ahenk unsuru seciyi sıklıkla kullanmış, böylelikle anlatımına ayrı bir canlılık katmıştır:

“Sac ādetlü, siyādetlü, semāḥatlü, melāḥatlü, ' izzetlü, mekremetlü, rif' atlü, mahmidetlü, diyānetlü, emānetlü, hạkịḳatlü, șadāḳatlü, mürüvvetlü, fütüvvetlü, lețāfetlü, țarāvetlü, ' ināyetlü, kerāmetlü” (vr. 1a)

\footnotetext{
48 "Kaderin emrine teslim ol ki rahat bulasın."

49 "Kerem sahibi Allah'a tevekkül ettik."
} 
“merhūnen bi'l-ḩayr ve's-sa āde rif' at ü iḳbāl ve niẓām-1 ḥāl ve șafā-yı bāl ile kām-bīn eyleyüp, rıżā-yı celīline muvāfiḳ a'māl-i mebrūre ve ef ${ }^{\mathrm{a}} \mathbf{l}-\mathrm{i}$ meşkūreye tevfiḳ ile mes ${ }^{\mathrm{u}} \mathbf{d}$ ve 'avāḳıb-1 āmāl ve emānīlerde meymūn u maḥmūd eyleye.” (vr. 11a-11b)

\section{Sonuç:}

Nazım ve nesir alanlarında birçok eser kaleme almış Süleyman Nahîfî’nin pek bilinmeyen Münşeât'1 ayrıntılı şekilde tanıtılmaya çalışılmıştır. Eser, edebiyat tarihimizde harem mensuplarının yazdığı mektuplar hariç tutulursa, sevgiliye yazılmış mektupların nadir örneklerinden birini teşkil eder. Eserdeki mektupların bir kısmı (2 ve 6. mektup), Nahîfî’nin orta yaşlı çağlarına; diğerleri ise (1, 3, 4, 5 ve 7. mektup) yaşl11ık dönemlerine aittir. 2. mektuptaki ifadeler, Nahîfî'nin rüya tabiri hususunda hayli bilgi sahibi olduğunun işaretidir. Aynı mektup içinde (8. mektup) farklı disiplinlere ait terimleri (gramer, kelâm, astronomi $v b$.) kullanması, Nahîfî'nin istediğinde sanat gücünü en iyi şekilde ortaya koyabileceğinin kanıtıdır. Şairin Dîvân'ındaki şiirlerinde kullandığı külfetsiz dil, samimi ifadelerle dolu âşıâne üslûp mektuplarına da yansımıştır. Nahîfî'nin mektuplarından, kaleme aldığı yeni şiirlerini tanıdıklarıyla paylaştığı görülmektedir. Mektuplarda örnekler sunduğu şiirlerin, şairin Dîvân'ının tenkitli metninde yer almamasından hareketle, bu şiirlerin bulunduğu nüshaların ya tenkitli metne dâhil edilmediği ya günümüze ulaşmadığı ya da mektuplara özel kaleme alındığı söylenebilir. 


\section{Münşe 'āt-1 Nahịifí}

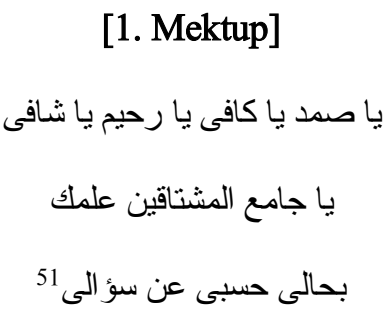

Sa ādetlü, siyādetlü, semāḥatlü, melāḥatlü, ' izzetlü, mekremetlü, rif ${ }^{\Upsilon}$ atlü, mahmidetlü, diyānetlü, emānetlü, hạakiḳatlü, șadāḳatlü, mürüvvetlü, fütüvvetlü, lețāfetlü, țarāvetlü, ' ināyetlü, kerāmetlü ben bende-i müştāḳına merḥametlü, şefḳatlü, muḥabbetlü, nūr-1 dīde-i giryānım ve sürūr-1 sīne-i sūzānım, ārām-1 dil ü cānım efendim, sulțānım hażretlerinüñ mübārek ḳadem-i sa' ādet-maḳdemi -ki cilvegāh-1 şāyestesi farḳ-1 serim belki hadeḳa-i baṣarımdur- hezār sūziş-i iştiyāḳ u ḥasret ve bī-şümār nāliş-i eşvāḳ u muhabbet ile çeşm ü müjgānım sūde ve rūy-1 ' ubūdiyyet-i ' unvānım fersūde [2a] ḳılındıg̀ı siyāḳda, farīża-i ' ayn-1 himmetim ve rehīne-i deyni żimmetim olan du` ā-yı bī-riyā-yı ' ömr ü 'izzetleri ve senā-yı müsteșnā-yı ḳadr ü rif ${ }^{\Upsilon}$ atleri, ' anșamīmi'l-cenāne bu resm-i dil-sitān üzere nigāşte-i șahịife-i ' arż u beyān olunur ki benim māye-i şevḳ-1 dil-i nālānım, benim mürüvvet ü merḥāmet kānı sulțānım, benim mānend ü nazịiri nā-yāb olan yār-1 dil-pesendim efendim.

Bu kār-ḩāne-i kā 'inātı ve bi'l-cümle mükevvenātı ḥavl ü ḳuvveti ve 'aẓamet ü ḳudreti ile ' ademden ìcād eyleyüp, țabāyi ‘ -i müsteviye-i eşyāda ve eşref-i mahllūḳ olup ism-i etemm-i Ādem ü insān ile mevsūm u mu'anven olan zāât-1 müsemmāda ve neşve-i dil-cūy-1 ta'alluḳ ile ḥüsn ü ' aşḳı nümūdār ü nümāyān eyleyen Hallāḳ-1 kevn ü mekān ve Rezzāḳ-1 ins ü cān

52 تعالى شانه عن الزمان و المكان و تقدست صفاته عن تطرق التغير و الحدثان gevher-i dürc-i şeref ü cemāl ve ahter-i bürc-i ḳadr ü kemāl olan vücūd-1 mes ūd ve zֵăt-1 mekārim-nübūduñı āfăt-1 bārize vü mekāmine ve 'āhāt-1 zāhire vü bāṭıneden maḥfūz [2b] u emīn ve sa'ādet-i dü-cihān ve 'izzet-i cāvidānī ile maḥfūẓ u kām-bīn eyleyüp, gencīne-i ș̣dḳ u ị̉ān, ḩazīne-i nūr u ỉmān olan ḳalb-i şerīfüñi kendi rıżā-yı ‘ālì-şānı ve Ḥabīb-i ekrem ü eşrefinüñ `aşḳ u muhabbet-i cāvidānī nūrıyla

\footnotetext{
${ }^{50}$ Münşeât'1n transkripsiyonunda, eklerin düzlük-yuvarlaklık durumuyla alâkalı olarak Hayati Develi'nin hazırladığg XVIII. yy Ístanbul'a Dair Risâle-i Garibe adlı eserdeki kullanımı dikkate alınmıştır. Bkz. Hayati Develi (haz.), XVIII. yy İstanbul'a Dair Risâle-i Garibe, Kitabevi Yay., İstanbul 1998.

51 "Ey herkesin kendisine muhtaç olduğu! Ey kullarına yardım eden! Ey merhametli olan! Ey sıkıntıları gideren ve ey âşıkları bir araya getiren! Hâlimi bilmen bana istek olarak yeter."

52 "Zamandan ve mekândan şanı yüce olan Rabbim! Onun sıfatlarını, değişmelere ve yeni şeylere erişmeye istemekten kutsal görürüm.
} 
münevver ve bi'l-cümle murādāt-1 dāreynüñi maḳrūnen bi'l-` izzi ve's-sa' ādet ve merhūnen bi'l'izzi ve's-selāmete maḳdūr ü müyesser eyleye.

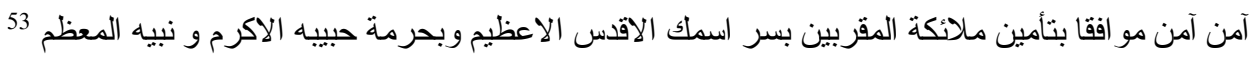

Āh benim muhabbetlü, ' ināyetlü efendim! Ne lisān ü lügat ve ne ta 'bīr ü ' ibārāt ile 'arż1 hulūṣ-1 muhabbet ve beyān-1 şürūṭ̂-1 'ubūdiyyet idecegim bilmem.

\section{Beyt}

Nice ḥāl-i dilimi eyleyem i‘ lām saña

Meger Allāh ide aḥvālimi ilhām saña

Va'llāhü’l-‘azịm benim mürüvvetlü, merḥametlü efendim. Bu küstāhāne cesāret-i bīedebāne ile efendimi tașdíc bī-ihtiyār-1 iştiyāk ve bī-șabr u ḳarār-1 hasret ü eşvāḳ oldıg̀ımdandur efendim. Egerçi 'aşk u muhabbetleri [3a] evvel mülāḳātda derūna eșer idüp, rūz-be-rūz ḳalbimde temekkün ü bürūz üzere idi. Ammā bi-emri'llāhi te ālā def' aten bir mertebe müşta 'il ü fürūzān oldı ki kemter şerārından șabr u iḩtiyārım mag̉lūb u maḳhūr ve ārām u ḳarārım meslūb u mestūr olup, şeb u rūzum belki her nefes dil-sūzum, ḩayāl-i meserret-me'ālleri ve endiş̧e-i hüsn ü cemāllerinde mevḳūf u maḥṣūr olmışdur. Bu ne hāalet-i garāỉb idiginde hayrān olmışumdur. Egerçi hengām-1 şebābdan bu āna dek, ḳatı çoḳ meşḳ-i ‘ aşk idüp ḥasret ü muḥabbet āteşlerinden mānendi kebāb nālān u bī-tāb oldum, ammā bu ser-gerdānlıg̀ı görmedim. Ġālibā eyyām-1 sālifede ārzū-


ve meşgūul olmag̉la çendān müte 'eșsir olmaz imişim. el-Hāletü hāżihī ḳalbimde nukūş-1 cāh u celāl ve hevā-yı māl ü menāl olmayup bi'l-külliye hulüvv ve șafvet üzere bulunmag̉la sulțān[1mın] muhabbetleri iḳlīm-i vücūdumı țūlen ve 'arżen żabṭ [3b] ü teshīir eyleyüp, aḥkām u fermānını murādı üzere temşiyet ü icrā ile cihāngīr eylemişdür.

Benim efendim, bu te ārüf ü muvāneset egerçi bilürüm tā ‘ālem-i ervāḥdan müşeyyed ve ma' ḳūddur, ancaḳ bu neşvede bu ḳadar şiddet-i zuhūr ü bürūzına ḩayrānım. Efsūna mı ug̉radım, meshūr mıyım, dīvāne mi oldum, memkūr mıyım āh efendim? N'olaydı ' abd-i müşterā olup şām u seher ḩıdmet-i şerīfüñde ser-geşte vü pūyān olaydım. Egerçi ma' nāda efendimüñ ' abd-i memlūk u maḥkūmı oldıġımda iştibāhım yoḳdur, ammā bi-ḥasbi’z-ẓāhir müntehā-yı emelim budur ki dem-ā-dem mürüvvetlü, merḥametlü efendimüñ hıdmet ü șoḥbetleriyle şād ü hurrem ve hāâk-i

53 “Âmin! Büyük nebinin ve kerem sahibinin habibinin hürmetine, yüce ve mukaddes olan isminin sırrıla yakınındaki meleklerin duasina muvafik olarak, âmin."

${ }^{54}$ Kur'ân-ı Kerîm, Mü'min Sûresi 40/44, "Ben ișimi Allah'a havale ediyorum." 
pāy-1 sa' ādetinde hem-rāh u hem-dem ve halvetinde enīs ü mahrem olup hayātımda merżā vü meşkūrı, memātımda mersāa (?) vü mezkūrı olam.

Efendim, saña bu 'arż-1 ḥāl-i müstemendāne belki efsūn ü efsāne gelir. Egerçi müțāla' ai faḳirānem üzere cüvān-1 pīr- aḳl ü daḳiḳa-dānsın, fehm ü firāsetüñ ve rüşd [4a] ü kiyāsetüñ ma‘nā-yı hāl ü müstaḳbeli ' ārif ve rāz-1 derūna vāḳıf oldıġına cezm ü yaḳinimim vardur, ancaḳ benim efendim eyyām-1 şebāb ve hengām-1 cüvānī vaḳt-i iltihābdur. Eger bu sūz u güdāzım ve enīn ü niyāzım, hakịiḳat üzere ma' lūm-1 țac -1 lațịf ve mefhūm-1 ḳalb-i şerīfleri olsa şem` iken pervāne ve gül iken bülbül-i ferzāne olmaḳ muḳarrer idi. Taḳrīr-i ḥāl-i derūna kemākān bir vech ile kāāir degilim. Ancaḳ benim efendim 'azametu'llāha ḳasem ki șigaār u kibār ve aḳribā vü ehịbbāda ve şāḥ ü gedā ve a' lā vü ednāda efendimüñ muḥabbetinden efzūn kimseye 'alāḳa ve muḥabbetim yoḳdur. Şöyle ki efendimüñ sebebi ile bi'l-iżāfe devlet-ḩāneleri dergehinde olan sā 'ile dahi iltifătım āḩardan ziyāde ve erbāb-1 sarāydan her kime 'arż u dād idersem, ḥaḳiḳati efendime rū-dāde idiginde iştibāh buyurmayasız ki bu beyt-i bedīhī tercemān-1 lisān-1 hāldür:

\section{Beyt}

Ne Selīm ü ne Süleymān [ne] Sinān u Selmān

Ben saña bendeyim ey şāh-1 ḥakiḳat- [4b] peymān

Va'llāhu'l-' aẓīm efendim, ' aşḳ u muhabbetüñ dil-i şūrīdeye bir mertebe te ’ṣī itmişdür ki 'aḳl ü fikrim, țaraf-1 pür-şereflerine merhūn ve lisān-1 cenānım du' ā-yı ḩayr u senā-yı cemīllerine mevḳūf u maḳrūn olup, bir laḥẓa ne dīde naḳş-1 hayāllerinden ḩālī ve ne sīne sūz-1 muḥabbetlerinden ġayr ile mālīdür. Ḥattā bu șabāḥ -ki șabāḥu'l-ḩayr-1 yevmü'l-ḩamīsdür ve ibtidā-yı donanma-yı nefîsdür- cünūd-1 țuyūrdan ḳamārī du` ācılarına vazịife-i faḳīāne olan erzenefşānde-i dest-i i tiyād olurken, mürüvvetlü efendimüñ teveccüh ü raġbeti dil ü cāna gaalebe idüp, neşr ü nișār üzre iderken 'Arabī ve Fārisī edā ile ba' de'l-besmele "c alā yedi Feyżu'llāh, be-desti pāk-i Feyżu'llāh" diyü ḳumrucuḳlara erzen-efşān-1 emānet-i du'ā oldum. Hieç bun1 yazmaḳ şīvei cünūndan aşag̉ı degildür, ammā efendim galeyān-1 'aşk ādemi böyle ḥayret-zede vü ḩallāṭ eyler. 'Afvları niyāz olunur.

Benim merḥametlü efendim, böyle șad-hezār evrāḳa șebt-i merāsim-i eşvāḳ [5a] u iştiyāḳ ve resm-i levāzım-1 muḥabbet-i ḥaḳiḳat siyāḳ olunsa mihr-i rahş̧āndan žerre ve baḥr-i ‘ ummāndan ḳaṭe beyānı emr-i muhāldür. Hulāṣa-i kelāma gelelim. 
Evvelā mürüvvetlü, sac ādetlü efendime vașıyyet-i șādıḳāne budur ki halvet ü celvetde, keșret ü vaḥdetde hallāḳ-1 kā 'inātuñ celle şānuhu żikr u fikrinden ḳalb-i şerīfüñi ve lisān-1 lațīfüñi ḩāli eylemeyüp, şefí ${ }^{`}$-i cümle-i müznnibīn ve delīl-i Müslimāt u Müslimīn olan eşref-i mevcūdāt ve efụal-i mahlūkāātuñ - 'aleyhi efḍalü’ṣ-ṣalavāt ve ekmelü’t-teslīmāt- sünnet-i seniyyesine șıdḳ u ihlāṣ ile iḳtidā vü iḳtifāya sa' y ü himmet ve 'aşk u muḥabbeti nūrı ile taḥsîl-i vecd ü hāale kemāl mertebe dikkkat ü ' azīmet eyleyesin -ki dāreynüñ sa ādeti ve kişinüñ selāmeti bunuñla ḥāṣıldurbundan mā' adā her ne var ise 'abes ü bī-ḥaṣ̣̂1 ve belā-yı cān ve mükeddir-i dildür ve cümle murādāt[uñ] bi'l-ḩayruñı șıdḳ-1 niyyet ile Allāhu 'azīmü'ş-şāndan țaleb ü recā eyleyüp, [5b] Māni` ü Mu`ṭi ve Nāfi` u Ḍārr ve Kāâir ü muḳtedir-i muṭlaḳ Ḥak idigine īmān ü iḳān eyle ve lākin bu ma'nālara 'avām-1 nās gibi mücerred lisān ile ḳāni' olma, ki bī-fầ'idedür. Da'vā-y1 tevekkülde olup, sulțān ve vezīr ḳapularında irtikāb-1 züll-i su'āl iden kezzzāb ve müdde îler evżā' indan Hudā'ya isti' āze eyle. Her ne ister iseñ Rabb'üñ aña ḳādir idigin taḥkikịan bilüp, șıdḳ1 talebde takṣiir eyleme. Maṭlūbuñ teheyyü'e-i esbāb-1 kāmile ile ẓuhūra gelirse الحمدله الذى بنعمته 55 diyüp, hayr idigin taḥkīk ve hamd ü şükre sac y-1 belìg ve cidd-i haḳịk ile mațlebüñ tekmîl-i esbāb-1 huṣūlden șoñra tehallüf iderse 'inde'llāhi te`ālā hayr olmadig̀ın bilüp, müteselli ol, "belki ben ḳulunı 'iṣmet itdi; ḩayırlı olsa ị̣sān iderdi, degil imiş müyesser itmedi” diyü ḥamd ü senā eyle.

Ḥāṣ11 benim efendim, iḩtiyāruñı iḩtiyār-1 Ḥaḳḳa merhūn eyleyüp, cemī' -i umūruñı ol Rabb-i Kadīre [6a] tefvīì ve tevekkül-i tāmm ve șidḳ u ihlāṣ ile zuhūrāta 'adem-i ta'rīż üzere olmag̉a ziyāde iḳdām eyle. "ملم الامر للقضاء نسترح"mażmūnıla ‘amel eyle. Mevlā-y1 Müte‘āl kبullarına cümleden erḥam ve ẓāhir ü bāṭı hāaline a' lemdür. ${ }^{57}$

S̄āniyen benim mürüvveti, merḥameti bī-ḥadd efendim, bu 'abd-i ḥaḳīi mübarek ḳalb-i şerīfüñden ib` ād ü ihrāc itmeyüp Rūm'da mıyım, Hiicāz' da mıyım ‘alā mā-yekteżīhi'l-ḥāl selām u kelāmuñla ya bir varaḳ-pāre-i bedī' ü’l-iḥtirāmuñla ḥayātda oldıḳca ḩâtı̣r-1 maḥzūnumı şād eyle. Eger taḳdīr-i Ḩallāḳ-1 Bī-çūn ile ḥasret ü iştiyāḳına tahammül idemeyüp ölürsem, cān-1 nālānımı ve rūḥ-1 revānımı Fātiḥa ve İhlāṣ ve du' ā-yı hayr ile mesrūr ve der-yād eylemeñi niyāz iderim. Eger mevt muḳadder ise mev' id-i mülāḳātımız, civār-1 sulțān-1 enbiyāda - ' aleyhi ef̣alü't-teḥāyāve firdevs-i a' lāda olmaḳ recāsın eylerim. الله عظيم الثان جل شانه وجم احسانه 58

\footnotetext{
55 "Bütün hamdler, nimetiyle sâlihleri kemâle erdiren Allah'a mahsustur."

56 "Kaderin emrine teslim ol ki rahat bulasin."

57 "Kerem sahibi Allah'a tevekkül ettik."

58 "Şanı büyük olan Allah'ın iyilikleri bol, derecesi çok yücedir."
} 
Bu rūzgārını [6b] hevā vü żünūb ve zellāt u ' uyūb ile żāyi` itmiş ḳulunı ol vücūd-1 şerīfini ' ālemlere raḥmet ve sāye-i şefā‘ atini melāž-1 ümmet itdigi ḥabīb-i ekremine -ṣalla'llāhu 'aleyhi ve sellem- hibe ve iḥsān eyleyüp, bilā-ḥisāb ve lā-' az̄āb cümle-i aḳibā ve eḥibbā vü aṣdiḳa ile cennāt-1 ‘āliyyātına idhāāl ve iṣāall itdigi ‘ ibād ve sü‘ edāsından eyleye.

آمن بسر اسمه الاعظم الاقد الاعلى 59

Efendim, Ḥaḳ te`ālā seni țūl-i 'ömr ile mu’ammer eyleyüp her hāalde rıżāàı şerīfine maẓhar ve cemī ${ }^{c}$-i murādāt u maḳșūduñ h hayr u sa ādet ve sühūlet ü selāmet ile müyesser eyleye ve vücūd-1 şerīfüñi āfăt u żarardan ve ḳalb-i şerīf ve țab -1 lațîfüñi ālām u kederden emīn ü sālim eyleyüp maḳāṣıd-1 dāreynüñi ḩayr ile hāạṣl ve derecāt-1 riżā-yı celīlinde mertebe-i c ulyā-yı ' izz ü sa'ādete vāṣıl eyleye, va'llāh ve bi'llāh.

Bu Ramażān-1 şerīf ve '1yd-1 meserret-elïfde şeref-i șoḥbet ü muvāṣalatları ve eșer-i muṣahhabet ü muvānesetleri berekātiyle cümle-i 'umūmda güz̄ār eyleyüp, [7a] Ramażānü'lmübārekīn ve a'yād-1 şerīfeye ġālib olup, belki her bir nefesim nice '1yd-1 sa'ideye bedel olmışdur. Efendim, ben efendimüñ bu ḳadar nüvāziş ü mürüvvetine ve luṭf u merḥametine, mücāzāt ü mükāfāta da'vāt-1 bi'l-ḩayrdan ġayrı nesne ile kāàir degilim. Ecrini 'ālemleri 'ademden vücūda getiren Vehhāb [ü] Kadīre havāle eyledim. تعالى شانه وتتو الى احسانه ${ }^{60}$

Benim efendim, ben faḳīüñ yanında māl ü cāh ve muḳārenet-i vezīi ü pādişāh zerre degildür. Benim naẓarım, şeref ü ḳadr ve ' izzet ü șıdḳ ve hulūṣ u mürüvvetedür. Bu ḩāletüñ ẓuhūrı ḥikem-i 'aliyye-i İlāhiyye'den bir ḥikmet-i 'az̧īmedür ki âsāāını inşāa 'allāhu te ālā dünyā ve āhiretde müşāhede eyledikde ma' lūm-1 'izzet olur.

Efendim, beni żāyi` eyleme. Başım ucunda, başım berāberi limonlar ve beriyye ${ }^{61}$ çiçegi ve sā 'ir 'ināyāt-1 behiyyeleri ḥırz-1 cānım ve tesliyet-bahşş-1 revānımdur. Ḥuṣūṣan fincān-1 pādzehr-i faḳirāne feyż-yāb-1 şuḳḳa-i mübārekeleri olmaḳ [h] od nīk-i ‘ömr-i cāvidāndan ma` dūd idigi [7b] bī-iştibāhdur.

\footnotetext{
59 "Yüce ve mukaddes olan ism-i azamının sırrı için, âmin."

60 "Mevla iyilikleri birbiri ardınca verir ve şanı pek yücedir."

${ }^{61}$ Çiçek isimleri hakkında yaptığımız araştırmada "beriyye çiçeği” isimli bir bitkiye rastlamadık. Müstensihin dikkatsiz olduğunu göz ününde tutarak, bu kelimenin yazımına benzer çiçek isimlerini taradık. "Beriyye" ile hemen hemen aynı yazılan "biberiyye çiçeği” adında bir bitki vardır. Mor çiçekli ve çalı görünümlü bitkidir. Akdeniz çevresinde yaygıın olarak yetişen bitkinin genç sürgünleri bahar olarak, kendisi ise süs bitkisi olarak kullanılır. Çiçekleri haşlanarak uyarıcı bir şurup elde edildiği gibi, "biberiye ispirtosu", kolonya $v b$. yapmaya yarayan değerli bir esans da çıkarılır. Ayrıca, yapraklarından yăg elde edilir. $B k$. http://tr.wikipedia.org/wiki/Biberiye (erişim 01.11.2014)
} 
Muḥabbetlü efendim, işāret-gerde-i `ālīleri olan ebyāt, kimer birḳaç ḳ1ț a olmaḳ üzere

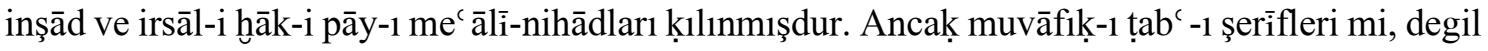
mi ${ }^{62}$ bilmem. Degil ise i` āde-i fermānları cān u başa geçer, fermān efendimüñ̃ür.

Mürüvvetlü efendim, içeri aḥvāli neye müncer oldı? Āh efendim, Ḥaḳ te ālā seni ḥüzn ü kederden ve hațā vü hațardan saḳlasın efendim. Mizāc-ı nāzeninnüñe elem ü keder virmeye efendim. Senüñ kederüñ, ben ḳuluña ḥavāle eyle. Rabbim seni dā 'imā ḥıfz u emānında eyleyüp, murād-1 şerīfüñ üzere memnūn ve mesrūr eyleye. Āmin efendim, āmin efendim.

Hुāk-i pāy-1 sa' ādetüñe, murād üzere ' arż-1 ḥāl muhạāl, ancaḳ fehm-i daḳiḳa-dān ve ' irfān-

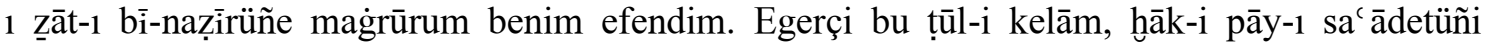

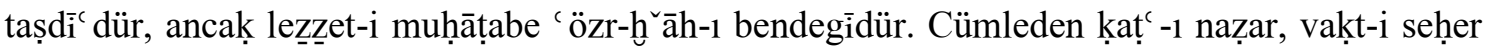
sāa at on birden țulū' -1 şemse dek bu ḳadar tahrrīrāt ve ta bīiāt, kullugiuma ve şevḳ-1 derūnuma şāhid degildür [de] nedür? ' Afv-1 ' ināyetüñ [8a] mercūdur efendim. Bu maḳūle riyāa-āmīz kelām söylemek nā-münāsibdür. Ancaḳ efendim, ỉkāż ve taḥdīs-i ni`met niyyetiyle söylerim.

Efendim, sen bir güher-i pāksin ve Cenāb-1 Ḥaḳ senüñ ḳalb-i şerīfüñe nūr-1 tevhīidi kemākān vedī'a eylemiş bir zâat-1 pākīze-șifătsın. Allāh'a emānet, kendüñi ziyāde muhāfaẓa eyleyüp, ḥıfẓ-1 Ḥaḳka ve 'ināyet-i Feyyāż-1 muṭlaḳa kesb-i isti` dād eyle. Ḥaḳ te ālā efendime țūli ‘ ömr iḥsān eyleye. Mīve vaḳt [ü] zamānında kemāl bulur inşā’ allāhu te ālā. Zַāt-1 şerīiüñ mațlac 1 huūrşīd-i ma'rifetu'llāh olacaġında şübhem yoḳdur. Çok çok șalavāt-1 şerīfeye meşgūul ol, seni Allāhu 'aẓimü’ş-şāna havāle eyledim. Ben ḳuluñı efendim du' ā-yı hyayrdan ferāmūş eyleme.

Benim 'ināyetlü, hakịịatlü, muhabbetlü, diyānetlü, șadāḳatlü efendim, bolay ki birḳaç gün dahi te 'hīir buyurulmag̉a himmet ve teveccühleri niyāz olunur. Nā-çār teşrīf-i ric' at lāzım gelürse bu 'abd-i müştāḳa ḳalem-i mübārekleri ile iki üç kelime olsun, ḥırz-1 bāzū-yı müfāḩaret olan nemīḳa-i [8b] dil-nüvāzları bī-dirīg buyrula ki āḩir-i ömrüme dek ḥırz-1 cān ve nāme-i emān ideyim.

Āh efendim, ḳaṭ -1 niyāz-nāme ideyim didikce, derd-i derūnum beni taḥrīk idüp, efendimüñ tașdíc ine cesāretden dest-keşīde olmag̉a ruhșat bulamam. Benim efendim hemān ḥ̣fẓ1 İlāhīde olup, șịhḥat u selāmet ve devlet ü sa ādet ile dā 'im ü bāḳi olasın. Her ḳime münāsib ise selām-1 fāḳīānemiz iblāg̀g[1] emr-i fermānuña menūṭdur.

${ }^{62}$ Metinde "deñilmez" şeklinde yazılmış, bağlam gereği yukarıdaki şekli tercih edilmiştir. 
Bāḳi emr-i fermān ve mürüvvet ü iḥsān, ' ināyetlü, ‘ ạṭfetlü, merḥametlü, şefḳatlü efendim sulțānımuñdur.

\section{[2. Mektup]}

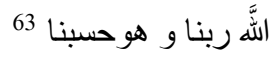

ZCāt-1 bī-şerīki aḳdes ü a' lā olan Rabbü'l-cālemīn تعالى شانه و تتو الى انعامه و احسانه 64 müsta idd-i feyż-i ḳudsī olan zāât-1 meleki's-simātların ekdār-1 hissiyye vü ma'neviyyeden emīn ü sālim ve maḳām-1 refíc-i șidḳ-1 'ubūdiyetinde ș̣hḥat u selāmet ve rif' at u sa'ādet ile șābit ü dā'im eyleyüp, țūl-i 'ömr ve 'āfiyet ile mu'ammer ve bi'l-cümle maḳāṣıd [9a] u [e]mānī-i dāreynlerin müyesser ü muḳadder eyleye.

$$
\text { آمن بسر اسمه الاعظم و بحرمت سينا حبيبه الاكرم صلى اللَّ تعالى عليه و على آله و صحبه وسلم } 65
$$

Ba' dez̄ā Hilye-i Şerîfe-i Ṣahịha murād buyurulmış. 'Ale'r-re'si ve'l-' ayn! İnşāàllāhu

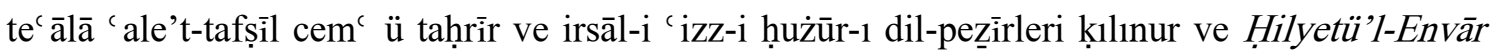
ismiyle müsemmā şerh-i manẓūme-i faḳirāne, perișān-tahrīi ü ebb-zede (?) ve ekșer mevāżic i maḥv u iṣbāt ve tebdīl ü taḥvīle muḥtāc olmag̉la bir vech ile şāfiye-i naẓar ü irsāl degildür. Hudāā ḥaḳḳıçün cān dirīì olmadıġı muhtāc-1 beyān degildür. Ancaḳ nüsḩa-i mezbūr[e]de birḳaç mülāḥaẓa dāmen-gīr-i ițâcat-emsāâldür ki ez-cümle biri o da satırdadur, redi kābil-i ḳırā'at degildür.

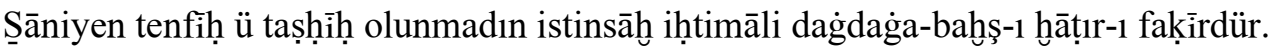

Sālișen muharrer olan dahi nā-tamām olup, beș altı cüz' ve hitāmında olan Ümmü Ma' bed rivāyeti gaayr-1 mektūbedür. Yohssa va'llāhu'l- aẓīm hilāf-1 riżā işāretlerine 'adem-i [9b] imtis̄āl emr-i muhāā idi. Bu mežkūrāt ma` lūm-1 sa`ādetleri oldıḳdan ṣoñra, elbette buyrulur ise yine dirīg olunmaz. Ancak ketb ü istinsāḥ olunmamaḳ ve itdirilmemek şarṭıyla meşrūṭ olursa luṭf idüp, huuṣūṣ-1 mezbūrda müsāmaḥamız bī-vefāyī vü nādānlıg̀ımıza ḥaml buyurulmaya.

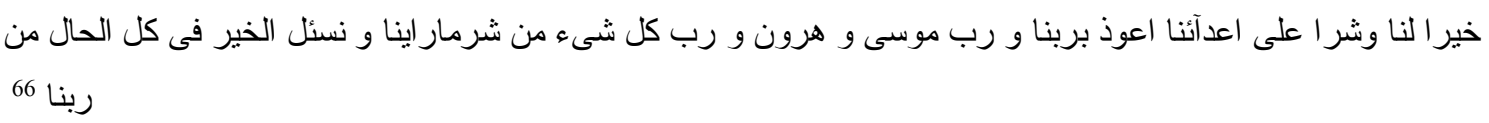

63 "Rabbimiz Allah ve o bize yeter."

64 "İyilikleri ve nimetleri birbiri ardınca verir ve şanı yücedir."

65 "İsm-i azamın sırrı için ve seyyidimiz, kerem sahibinin habibi hürmetine, âmin. Allah ona ve onun ailesi üzerine salât etsin."

66 "Hayır, bizim üzerimize, şer de düşmanlarımızın üzerine olsun. Bizi kaplayan bütün şerlerden bizim rabbimiz olan, Musa ve Harun'un rabbi ve her şeyin rabbi olan Allah'a sığınırım. Her durumda rabbimizden hayırlı olanı dileriz." 
"Ṣaḥā" emeldür, ya'nī mațlebdür ve refịk yār-1 șādıḳdur. Yā șūrī yā ma'nevī "ḥayye tasalluṭı" nefs-i emmārenüñ ba' $\dot{z}-1$ mekīdetinden işāretdür ve "oḳlar" sihām-1 du'ā ve zikr-i Hudādur ki anuñla a dā-yı șūrī vü ma' nevi țard [u] ibcād olunur. Oḳları gördükde, mübā' adatı ḥıfẓ-1 Bārī ḳarīn-i zātuñoz olup, žikr ve da` vāt-1 şerīfinüñ ḥüsn-i ḳabūline ` alāmetdür.

“Ardınca țaş aṭmaḳ ve hayyeye bālig olmamaḳ”, henüz helāk-i 'adūya taḳdīr müsācid olmayup, vaḳt-i ḳarībde ihlākine dālldür.

"Yere gömülü mār", a' dānuñ dā 'imā vaḳf ve mār olmasina işāret olup, [10a] öbürüne gösterilmek helāk-i 'adūy1 te 'kiddür. ${ }^{67}$ اللهم اهلك اعدائنا و سلمنا مكرهم بحولك يا رب Darr-1 mār ü 'aḳrebden, uyhuda ' ibād-1 Hudā ḥıfạa melā 'ike-i ḥafaẓa ile mașūn u maḥfūz oldığ gibi hemvāre ḳullarını Cenāb-1 Rabbü'l-‘ ālemīn mekr-i a'dādan emīn eylediginde iştibāh eylemeyesiz ve yılana kendi habās̄et-i zāatiyyesi ' adū olup, her kim görürse ḳatline mübāderet itdigi gibi a' dāya

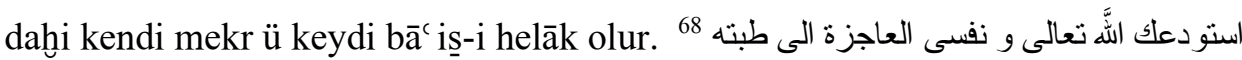

"Ḩāk-i pāye varılmaḳ", 'alāḳa-i rūḥāniye ile hayr du'ālarında olundiġına işāretdür. Birḳaç eyyām muhāceret-i șūrīden teşekkī, inşāa allāhu te ālā țarafeynden iḩlāṣ-1 tāmm olup, ‘ ādet-i asdiḳā üzere ‘ inde'l-mülākạât geregi gibi ‘ arż-1 muhabbet [ü] vidāda dālldür.

"Vāḳı ada ta' bīr-i vāḳ̂' a" șūrī ve ma'nevī sa'ādet ü iḳbāl ile ber-hūurdār ve kām-yāb olmalarına teveccüh-i faḳīrāne 'alāmetidür.

“Kahve içüp, eglenüp, țaşra gitmek”, bundan aḳdem [10b] eḳall-i ḳalīl mülāḳāt ile henüz seyr-i [ç] eşm-i ümmìd oldıġıma işāretdür ki inşāallāhu te ālā ḳarỉben ḩayr ile mülāḳāt ve muvāṣalat niyāz olunur.

“Çekmecede kāġıdlar var dinilmek”, șahịife-i ḳalbe naẓar eyleñ, aḥvāl-i hicrān ma' lūm olur, dimekdür.

“ Aẓim hüzn ile olmaḳ gibi görünmek”, bi-fażli’llāhi te ālā sürūr-1 'aẓim ile mesrūr olmag̉a işāretdür.

"İşte buraya geldik, bunda dahi āfetlerden emīn olmadıḳ, ḳahvemizde dārū var imiş dinilmek", fi'l-cümle eşgāāl-i dünyā sebebi ile 'ahd ü mīsāḳ hilāfı kemā-yenbaġīi hıdmet-i du'ālarında iḳāmet eylemeyüp, bi-ḥasbi'l-beşeriyye sehv ü gaflet faḳire tenbīhdür ki Ḥaḳ

\footnotetext{
67 "Ey Allahım! Düşmanlarımızı helâk et ve kudretinle onların hilelerinden bizi selâmetli kıl."

68 "Seni yüce olan Allah'a ısmarladım ve âciz nefsimi de onun yumuşaklığına emanet ettim."
} 
sübhānehū ve te'ālādan 'afv1 ve telāfì-i mā-făt recā ve niyāz olunur. ${ }^{69 ، ، ~ ا ل ح م د ~ ل ل ه ~ ث م ~ ا ل ح م د ~ ل ل ه ~ " ~ c u ̈ m l e s i ~}$ güzel terkībdür. Șūretā muvahhiş görünür, ammā degildür. Ḩâtṭr-1 şerīfüñüze zerre keder getirmeyesiz. Her ḥālde sizüñ ve bizim hââı u nāṣırımız ve mu ìn [ü] dest-gīimiz Allāhu 'azīmü'ş-şānı -'azze ismuhu- ve şefĩ -i mülāzımımız seyyid-i 'ālemiyān habāib-i Huudā'dur sallā’llāhu 'aleyhi ve sellem- [11a] Ba'de'l-'aṣr gelinmekle taḥrīr-i varaḳaya egerçi zamān müsā' id olmadı, ancaḳ bu ḳadarca tesvīdāt ile icrā-yı lāzime-i 'ubūdiyyet ve imtis̄āl-i emr ü mu āşeret ${ }^{70}$ ü ițâ̄' at olundu. Bi'l-cümle ḳușūrumı ' afv buyrulmak, recā ve niyāz olunur ve böyle pejmürde kāġıd ma' zūr olsun, hemān ḥāżır bulunmag̉la ihtiyār olundı. Ḳuṣūr çoḳ, bu dahi biridür. Maḳșūdına müncer ise i` āde-i ḩaber buyurmaları mercūdur.

Bāḳi hemisşe Hudā-yı Müte āl'üñ ḥ̣fẓ u emānında emīn olup, hațā vü hațarlardan bi'lcümle elem ü kederlerden emin olasız.

el-` Abdü Nahịifì Meḥemmed Süleymān.

\section{[3. Mektup]}

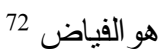

Feyyāż-1 sābiğg'n-nic am ve Vehhāb-1 sābıku'l-kerem ${ }^{73}$ - تعالى شانه و تتو الى احسانه muḥabbetlü, ḥaḳiḳatlü, sadāḳatlü, mürüvvetlü efendimi her ḥin ü ān ḥıfż-1 bī-zevālinde emīn ve merhūnen bi'l-ḩayr ve's-sa' āde rif' at ü iḳbāl ve niẓām-1 ḥāl ve șafā-yı bāl ile kām-bīn eyleyüp, rıżā-yı celīine muvāfıḳ a' māl-i mebrūre [11b] ve ef âl-i meşkūreye tevfịk ile mes ūd ve ‘avāḳıb1 āmāl ü emānīlerde meymūn u maḥmūd eyleye.

Benim nūr-1 çeşmim, dil-nüvāzāne firistāde-i mürüvvetleri olan şef[kat]-nāme-i girānmā[ye]lerinde gazel ḩaberinden tekeddür, ba' dehū memnūniyyet-i bendegī mün'akis-i mir'āt-i żamīr-i ṣafā-simātları oldıḳda متابعت المو لا لعبده memnūn ve müteselli oldıḳları ifāde buyurulmış. Haḳk te`ālā vücūd-1 mekārim-nümūduñı ālām u ekdārdan mașūn eyleyüp țūl-i 'ömr ile mu'ammer eyleye. Bu 'abd-i bī-miḳdāruñ naẓar-1 i' tibārında 'azl ü naṣb müsāvī belki gubār-1 giyāha mütesāvī idigi inşā 'allāhu te ālā ālūde-i levṣ-i riyā degildür. Mevlāü'l-mevlā olan Hudā-

\footnotetext{
69 “Allah'a hamd olsun sonra Allah'a hamd olsun."

${ }^{70} \mathrm{Bu}$ kelime metinde "mu'āderet" şeklinde yazılmıştır. Bu sözcüğün mânâsının bulunmaması ve bağlam gereği "mu'āşeret" kelimesi uygun görülmüştür.

71 "İsm-i azamın hakkı için âmin, âmin, âmin."

72 "O (Allah) çok verendir."

73 "Onun ihsanı bol ve şanı yücedir."

74 "İsm-i azam hakkı için âmin."

75 "Efendi kuluna tâbi olarak..."
} 
yı Müte` āl celle celālühü’l-`āli kendi ḳullug̉ı sa ādet ü şerefin bilen ḳulları zümresinden eyleyüp, 'azl-i ebedī-i hicrāndan șaḳlaya ve şeref-i iżāfî ile faḩr ü mübāhāt idenlerden eylemeyüp şeref-i zāâ̄i ile iki cihānda mümtāz ve serv-i ser-efrāz eyleye. ${ }^{76}{ }^{76}$

Benim sulțānım, üç ḥoḳḳa-i ferah-bahşā ve ḩāric-i țavr-1 ta`zīr ü terbiyet [12a] iki žülbend-i dil-bend -ki birine "Çekme" ve birine "Yemenī" tac bïr olunur- şeref-bahş-1 vușūl oldıḳda, sūzende-i yār-i iştiyāḳ olan ḳalb-i müştāḳa reşhạ-pāş-1 tesliyet ü sürūr olmışdur. Gūyā bī-cān idim, cānım; yā ḥaste idim, dermānım geldi. Cenāb-1 Ḥaḳk zāât-1 hakạiḳat-simātuñı huațāsız eyleye. Ṭaraf1 pür-şerefüñe olan iştiyāḳ u incizāābım ve 'alāḳa vü tehāābüm beyān idemem. Bu sūz-1 derūn hịç degil, illā ebr-i ḩulūṣ u ḥaḳiḳate ve eșer-i te`ārüf-i ‘ ālem-i ervāḥ ve șafvet idigi bī-iștibāhdur:

\section{Beyt}

Müjde kim geldi haber ol şeh-i hū̄ānımdan

Düzd-i ārām olan ārām-1 dil ü cānımdan

Benim māye-i sürūr-1 derūnum sulțānım. Cenāb-1 vālā-nișāba bu ta' alluḳ-1 rūhānīi bir vech ile ḳābil-i beyān degildür. Muḳaddem muḥabbet-nāme-i ' āliyeleri vürūdından bir iki gün muḳaddem, ' ālem-i menāmda şeref-yāb-1 șoḥbet ü mülāḳātları olup, zֵevḳ u şevḳ ile bīdār olundıg̀ı -ki iş`ār olunmış idi- ol vaḳ anuñ 'aḳibinde yine ḩ h̄āb-1 istirāḥat hilālinde luṭen ve keremen lețāfet-i rūhāniyetleri șūret-nümā-yı āyīne-i [12b] bāl ve meşref ${ }^{77}($ ?)-efzā-y1 ' ālem-i mis̄āl olup iktisāb olunan ma'nālar ma' lūm. Benim efendim ne diyeyim? Du`ā-yı hyayrdan gayrı nesneye ḳādir degilim. Hemān Haḳk celle ve ' alā vücūd-1 şerīfüñi ḥıf̣ u emānında eyleye, ne ḳadar 'arż1 iştiyāḳ ve 'ubūdiyyet eylesem yine murādım üzere ifāde-i merāma ḳudretim yoḳdur. Ġaraż 'arż1 ' ubūdiyyet ü ihlāṣdur. Bu 'abd-i hāaliṣ ü müştāḳları hāṭ̂r-1 şerīfden mehcūr buyurulmayup, ' idād1 eșdaḳ-1 aṣdiḳādan ma dūd buyurulmaḳ niyāz olunur. Bir vech ile tafșīl-i ḥāle ḳudret-i maḳāl yoḳdur.

\section{Kitt $\mathbf{a}-\mathbf{i}$ Bedihi $\bar{i}$}

'Arż-1 dā‘ ì-i kemīne böyledür

Pīşgāh-1 rif́ at-i cānānıma

Nāme-i ‘ anber-şemīm ü müşgbār

\footnotetext{
76 "Onun faziletinin hakkı için âmin."

${ }^{77}$ Metinde bu kelime "müşerref" okunacak şekilde "ş̧edde" işaretiyle yazılmıştır, ancak "müşerref-efzā̄" tamlamasının mânâsı tam olarak anlaşılamadığından "meşref-efzā" tercih edilmiștir.
} 
'Iṭr-sāy oldı dimāgà-1 cānıma

Luṭf-1 mevfür ${ }^{78}-1$ lațīfi eyledi

Șıdḳ u iḩlāṣ[1m] füzūn sulțānıma

Her edā-yı dil-güşā senden ' 1yān

Būy-1 şefḳat bu dil-i nālānıma

Eylesin zātuñ hațālardan emīn

Bu du' āyı eylerim Mennān'ıma

Hem hedāyā-yı nüvāzişkār ile

$B \bar{a}$ is olduñ şevḳ-1 bī-pāyānıma [13a]

' Üç ' aded dühn-i hazīne hem-dahi

İki ḳ1 ț a destmāl-i gānime

'İzzet ü ikrām ile iclāl ile

Vāṣıl oldı ' uhde-i peymānıma

Gerçi teklïf-i hediyye ḳaydı yok

'Abd-i memlūk-i şeh-i hūbānıma

Lìk kendi lutf-1 tab` uñdur sebeb

İltifăt-1 țab ${ }^{`}-1$ ma`nā-dānıma

İki ` ālemde ser-efrāz olasın

Bu niyāzı eylerim Yezdān'ıma

'Așḳ ile bülbül gibi nālān iden

Ben ġarỉbi sen gül-i ḩandānıma

Gül gibi itsin güşāde hāṭtıruñ

Nūr-bahşş ol dīde-i giryānıma

Bāa iș-i ma mūrīi-i ihlās ola

Feyż-i ‘ aşkụuñ ḩāṭır-1 vīrānıma

Hुıdmetüñ itmek du`ā-yı hayr ile

${ }^{78}$ Metinde bu kelime "mefhūm" okunacak şekilde yazılmıştır, ancak bağlam gereği "mevfūr" tercih edilmiştir. Ayrıca bu kıtanın tamamı Ali Cânib'in makalesinde yer almakta olup söz konusu kelime orada "mevfūr" şeklinde yazılmıştır. $b k$., Yöntem, age., s. 423. 
Lāzım oldı sen meh-i tābānıma

Bendeyim sulțānıma iḩlāṣ ile

Zerreyim sen mihr-i `ālī-şānıma

'Abd-i müştāḳuñ Nahịifí ' arż ider

Hāālini sen āfet-i devrānıma

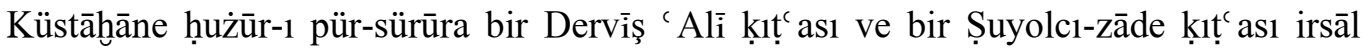
olunmışdur. Karīn-i hü̈n-i ḳabūl buyrulmaḳ mercūdur.

Bāḳi hemişse șıḥhat ü selāmet ve rif́r at ü sa ādet ile ber-murād olup, her ḥin ü ān ber-vefḳ1 rıżā, sürūr-1 dil-şād olmadan ḩālì olmayasız.

el-` Abdü Naḥîfì Bā-Süleymān [13b]

\section{[4. Mektup]}

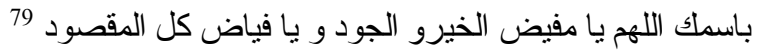

Var ey peyk-i șabā dil-dāra benden çoḳ selām eyle

Kemāl-i iştiyāḳım söyle teblì̉ gei peyām eyle

Sa ādetlü, meveddetlü, mekremetlü, șadāḳatlü, māye-i feyż-i dil ü cānım efendim, sulțānım hażretleri. Huudā-yı Zü̉'l-celāl ve Hudāvend-i vāhibü'l-āmāl, gevher-i yektā-yı șadef-i ‘ irfān ve ahter-i garrā-y1 şevḳ-1 bī-pāyān olan zāat-1 maḥmidetü’ṣ-ṣıfātuñı ṣıḥhat ü selāmet ve rif' at

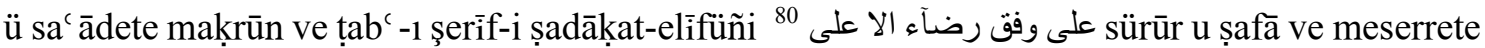
merhūn eyleyüp, fażl u kemālāt ve țậăt u 'ibādāt ie mu'ammer ve bi'l-cümle murādāt $u$ makṣūdāt-1 dāreynlerin müsehhel ü müyesser eyleye.

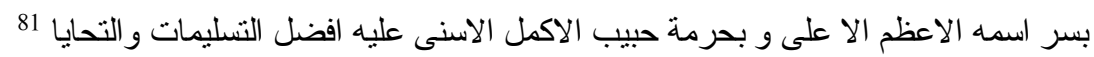

Benim sa` ādetlü efendim, sulțānım, ‘ arż-1 ḥāl-i bende-i du' ā-pişse budur ki:

\footnotetext{
79 “Ey hayırları ve cömertlikleri bollaştıran ve bütün maksatları bereketlendiren Allah'ım! Senin isminle (başliyorum)..."

80 "Yüce rizasına uygun olarak."

81 "Yüce ism-i azamın sırrı için ve yücelikte kemâl bulmuş habibinin hürmetine. Selamların ve duaların en faziletlisi onun üzerine olsun."
} 


\section{Beyt}

N'ola hạasretle füzūn olsa benim efḡānım

' Āşı1ḳuñ yañşaḳ olur ḥasteligi sulțānım [14a]

mıṣdāḳınca egerçi ḥāşā ḩāk-i pāy-i şeref-nümāların tașdī‘ dür, ammā efendime kemāl-i ‘ ubūdiyyet ve șadāḳat-1 müstemendāne iḳtiżāsıyla ba' żı fevā'id-i Fārisiyye tenmīk olunup, hezār şerm-i ' ācizāne ile firistāde-i cenāb-1 vālā-niṣābları ḳılındı. Dergāh-1 Ḥaḳ’dan niyāzım budur ki ṣıdḳ u hulūs-1 derūna vā-beste olmag̉la menfa'atden ḩālì degildür. Țaraf-1 pür-şereflerine kemāl-i incizāb u ta'alluḳum 'allāmu'l-g̉uyūba ma' lūmdur. İllā āyā ne țariḳ ile ḳudretim mertebesi maẓhar oldığım ni`am-1 celīle-i İlāhiyye’yi, efendime vāris ideyim diyü, mülāḥaẓa eșnāsında

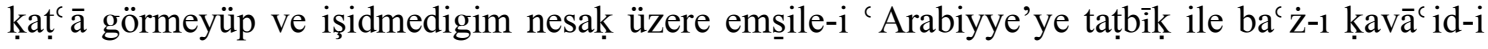
Fārisiyye beyān itmek bābında, bir nümūne ve bend ${ }^{82}$ ihtirāê $^{c}$ olunmışdur ki şāyeste-i naẓar-1 rag̉bet ü ic tibārları olursa dahi a' lāsı mümkindür.

Āh benim muhabbetlü efendim, n'eyleyim? Nesneye kāadir degilim... Yohssa va'llāhu'l' aẓīm zamān-1 ḳalīlde celīl ü ḳalīl mālik oldıġım ma' ārif-i külliye vü cüz'iyyeyi tā-ser-hā (?) țab' 1 lațîf ve fehm-i şerīflerine ifrāg u u ilḳā minnet-i cān-1 'azīzim idi. Ancaḳ medār-1 [14b] tesliyetim budur ki bu 'abd-i ḥaḳirine bilā-isti' dād ve bu ḳadar ma' nā-yı ra' nāyı i' țā vü iḥsān iden Perverdigār, efendime ān-1 gayr-1 münḳasımede luṭf u i' țāya ḳādir ve 'ibād-1 'acz-i' tiyādına lāyü` ad ve lā-yuhṣā fażl-1 bī-çūnı ve feyż-i rūz-efzūnı zāhirdür. Tażarru` u niyāzım budur ki vücūd1 mevdūd u mes 'ūduñı, ' ilm ü kemāl ile ārāste ve hüsn-i a' māl ile pīrāste eyleyüp, beyne'l-aḳrān ve'l-emsāl mümtāz ü ser-efrāz eyleye.

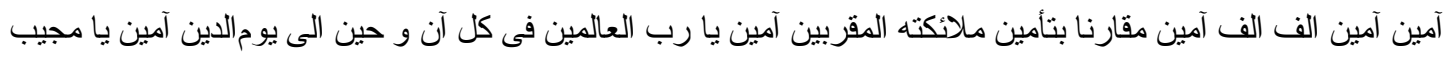

Ḥaḳ sübḥānehū ve te ālā efendimi ḥıfẓ u emānında emīn ve țūl-i ‘ ömr ve rif' at ü sa' ādet ile kām-yāb u kām-bīn eyleyüp, dünyā ve āhiretin ma' mūr ve ḳalb-i şerīin mekşūf u mesrūr eyleye. Āmin.

Benim efendim, benim sulțānım. Va'llāhu'l-' aẓīm saña kemāl-i muhabbetimi ve ṣıdḳ-1 'ubūdiyyetimi bir ḥāl ile ta' rīf ve tavșīfe ḳādir degilim. Zīrā ḳațarāt-1 deryā ve zenrā̄t-1 mihr-i

\footnotetext{
${ }^{82} \mathrm{Bu}$ kelime, metinde "bende" şeklinde yazılmış; bağlam gereği yanlış yazıldığı düşünülerek "kitap bölümü" mânâsındaki "bend" şekli tercih edilmiştir.

83 "Âmin, bin(lerce) kere âmin, mukarreb meleklerine yakın olarak âmin. Ey âlemlerin Rabbi! Din gününe kadar olacak her ânımızda âmin. Ey isteklere icâbet eden âmin."
} 
cihān-ārāyı ta' dād ü ihșāa mümkin olursa, efendime nūr-1 dīde-i cānıma ạ̣vāl-i dil-i [15a] şūrīdeyi i' lām ü ifhām mümkin olur.

\section{Beyt}

Bildirürdüm derdimi bir āh ile cānāna hep

Korḳarım sūz-1 derūnımdan felekler yana hep

beytini 'aceb yazsam mi? Hele dursun.

Benim efendim, benim sulțānım Allāhu 'azīmü'ş-şān seni hạtar u kederlerden ve bednaẓardan emīn eyleyüp, șafā-yı ḳalbüñi efzūn eyleye.

\section{Beyt}

Aġlasam ben gam degil sen gül hemān

Ġoncesin ey nev-cüvānım gel açıl

Āh benim efendim, ben ‘ abd-i ża ‘ îf bir zerre-i nā-çīzden eḳallim, amma bu faḳirüñ ḥālini kimse fehm eylememişdür, illā iki gevher-i pāk-derrāk -ki biri neşve-i pākīze-i sa ādet idi ki ḩālā derūnum şerāre-i muḥabbeti ile sūzāndur ve biri șadāḳatlü, haḳịkatlü, diyānetlü efendimdür- Su'āl olunur ise ki "Bī-çāre, senüñ miḳdāruñ nedür ki ḥattā seni dünyāda kimse bilüp añlamaya?" Efendim benim meselim, ol nüsha-i nā-yāb gibidür ki ben aña șaḥhāf maḳāmındayım. Bir șaḥhāf1 bī-māye ḩatțen ve ḳadren bir kitāb-1 nā-yāba mālik olup, "Ben de bir kitāb vardur ki dünyāda nazīiri yoḳdur ve kimse mālik degildür" dise, aña şeref-i zāâtı lāzım gelmez, [15b] kez̄ālik bu


kāaildür. Ben ol cevher-i ' ālì-şāna emīn-i mișālīyim. Tevbe efendim, nefs-i zāāim beni, hodfurūşluḳ vādīsine taḥrīk itdi, halṭ-1 kelām eyledim. Kemāl-i şevḳımdan elime ḳalem aldıḳça tașmīm itdigim ma' nālar, bi'l-cümle hāṭ̂rımdan züuhūl idüp, ne tahrīir idecegim bilmem. Benim ' ināyetlü, merḥametlü efendim, benim aḥvālim müşkil oldı. Raḥmān [ve] Rahịim olan mevlā-y1 Kerīm celle şānuhu șabr u ārām ve 'ināyet-i hayr-encām ile tesellïler ị̣sān eyleye. Va'llāhu'l' aẓīm ne namāzda ne sā 'ir evkāâtde efendimüñ ḩayāli ve naḳş-1 cemāli naẓarımdan mehcūr olmak muhāldür. Ammā efendim, bilmem ki ben garāib ü nā-çārı mübārek ḩạtır-1 pāk ve żamīr-i derrākine getirür mi?

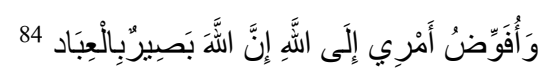

\footnotetext{
${ }^{84}$ Kur'ân-ı Kerîm, Mü'min Sûresi, 40/44, "Ben işimi Allah'a havale ediyorum. Şüphesiz Allah, kullarını çok iyi
} görendir." 
Benim efendim, cünd-i ḳamārī her seḥer ' alā yedi Feyżu'llāh ' unvānıyla erzen-efşān olup efendime lisān-1 ḥāl tesbīhüñiz siyāḳında du' ā-yı ḩayr eyleñ diyü, Mecnūn-1 'Ādīye şebīh ḩālet zuhūr ider oldı. Encāmı ḩayr ola benim efendim.

Dü destim ref ${ }^{\complement}$ idüp [16a] dergāh-1 Ḥaḳkạa söyledim tārīh

Mu' ammer eylesin Şeh-zāde 'Abdü’l-Mālik’i Mevlā̄

diyü iki ziyāde ta' miyeli tārīh inşād olundı. Efendime münāsib ise mülāḥaẓa buyurasız ve ebyāt1 cedīde-i bedīheden zuhūrāt bunlardur:

Sevdim ol mehveşi kim rūy-1 dil-ārāsı güzel

Hüsn-i aḩlāḳı güzel hilḳat-i zībāsı güzel

Nuṭḳ1 cān-bahşs-1 șafā ḩandesi efsūn-1 vefā

Ġamzesi ‘ işve-nümā seyr ü temāşāsı güzel

\section{Zemīn-i Āhar}

Nev-bahār oldı açıldı gül-i ra' nā ne güzel

Başladı naġmelere bülbül-i şeydā ne güzel

Yā ḳabādur yā ‘ abā ḥüsnini efzūnter ider

Yaḳışur cāme-i nāz ol şeh-i hūbāne güzel

Ele āyīne alup hüüsnüñe sen de naẓar it

Güzelim gör ne güzelsin güzel ammā ne güzel

Kạddüñ a' lā güzel ol ‘ārıż-1 tābende didim

Sevdigim döndi didi nāz ile a' lā ne güzel

Vay vay be hey yādigār! Bu oḳunur mı, diyü buyursañuz [16b] ḳuluñuz hayretde ḳalup, cevāba kādir olamam.

\section{Beyt}

Gāh cevr eyler-ise gāh vefā böyle gerek

İşte dil-dār-1 vefā-pīşe baña böyle gerek

\footnotetext{
${ }^{85}$ Mısranın sayı değeri 1123 'tür. İlk mısradaki “dü” ifadesi mısraya iki eklenmesi gerektiğini bildirir, böylece çıkan sonuç 1125 olur ve 1713-14 yıllarına tekabül eder.
} 


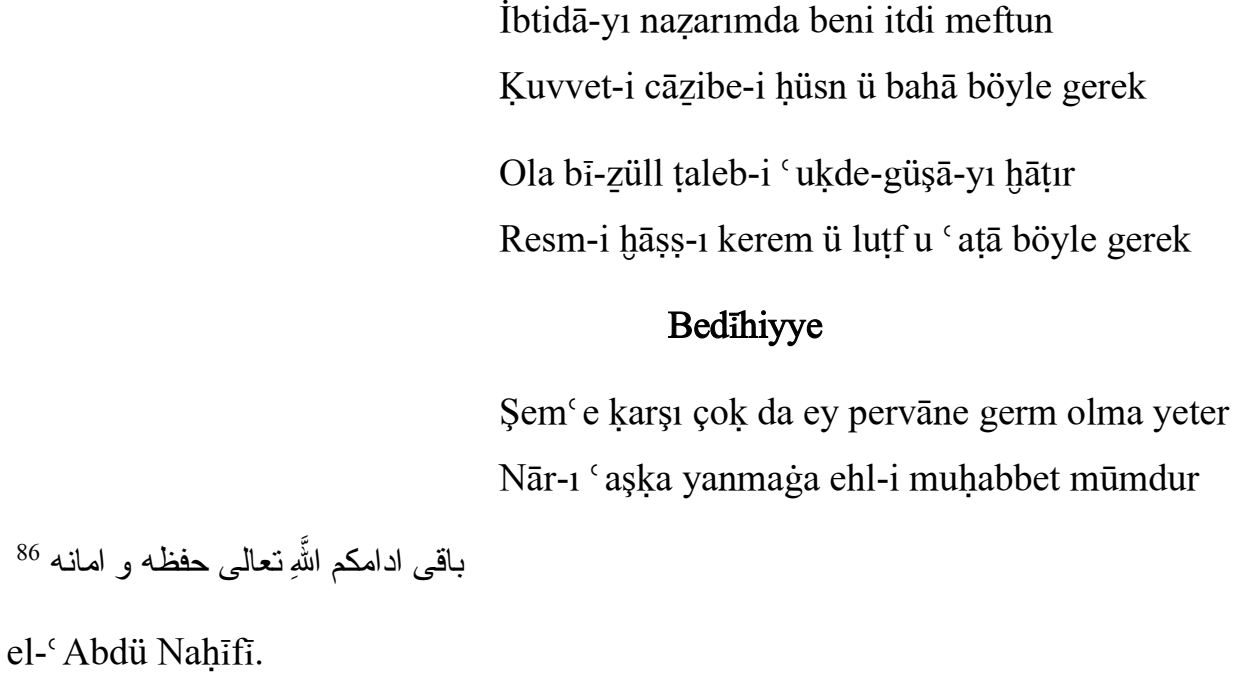

İbtidā-yı naẓarımda beni itdi meftun

Ḳuvvet-i cāzibe-i hüsn ü bahā böyle gerek

Ola bī-žüll țaleb-i c uḳde-güşā-yı ḩāṭ̂r

Resm-i hāṣṣ-1 kerem ü luṭf u 'aṭā böyle gerek

Bedihiyye

Şem`e ḳarşı çoḳ da ey pervāne germ olma yeter

Nār-1 'aş̧̣a yanmagia ehl-i muḥabbet mūmdur

باقى ادامكم اللَّهِ تعالى حفظه و امانه 86

el-`Abdü Nahịifi.

\section{[5. Mektup]}

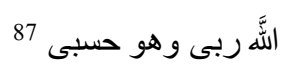

Dil-dāra șabā var yüri teblìge-i peyām it

Benden o şeh-i hüsne hulūṣ üzre selām it

Ahlāḳ-1 ḥamīde ve evșâf-1 pesendīidesine şāyeste ta' bïr-i belìg ile 'arż-1 'ubūdiyyet ve iştiyāḳda ḳaṣṣ oldıġım muhabbetlü, hakịiḳatlü, șadāḳatlü, mürüvvetlü efendim. Ḥaḳ sübhānehū ve te ālā zâat-1 sütūde-ṣıfâtuñı ḥıf̣ u emānında emīn ü sālim ve ș̣ḥhat ü selāmet ve rif at [17a] ü

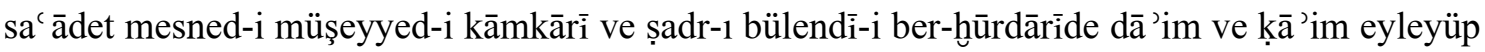
dünyā ve āhiretde rāżì oldığı ḳullarından eyleye.

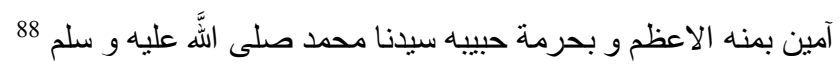

'Arīża-i bendegī budur ki benim nūr-1 çeşm-i cānım sulțānım. Geçen gün firistāde-i şefḳatleri olan nüvāziş-nāme-i 'ālileri şükrine bir vech ile ḳudretim yog iken, hāāā resānende-i ' ubūdiyet-nāme Küçük Ḥelvācı bendeleriyle hem-reng-i hū̄n-ābe-i ḥasret, nemiḳa-i cān-bahşş-1 merḥametleri şeref-bahşs-1 vürūd oldıḳda va'llāhu'l-' aẓīm iktisāb olunan feyż-i derūn ḥavza-i ta'bīrden bīrūn olup, lisān-1 hāl ü kạal ile dergāh-1 Rabbü'l- ālemīne firistāde-i darā' at ḳ1lınan da' vāt-1 bi'l-ḩayr ve eșniye-i cemīle inşāalallāhu te ālā zuhūra gelicek āșār-1 seniyyesinden ma' lūm olur. Şeyh Efendi pederüñizüñ da'vetinde, 'ale's-seḥer ḩ`ābdan bīiār ve kenār-1 baḥre

\footnotetext{
86 "Yüce Allah sizi daima muhafazasında ve emânında bulundurmaya devam etsin."

87 "Rabbim Allah ve o bana yeter."

${ }^{88}$ Büyük ihsanı hürmetine âmin. Sevgilisi, seyyidimiz $H z$. Muhammed -Allah ona salât ve selam etsin- hürmetine âmin.
} 
nāẓır șuffede tenhā oturup, mānend-i Mecnūn gāh nesīm-i șabāya hịṭāb, gāh baḥr-i ' ummāna 'arż1 1żțrāb ile girye-i cān-sūz eyleyüp, dỉde-i giryānda çehre-i [17b] zerdime rīhte-i hạsret olan dānei sirişk deryāya mütekāṭ̂r olup, sūz-1 derūn ve naḳş-1 füzūnuma işhād olunmışdur.

Va'llāhi, va'llāhi benim efendim, șabāḥ u şām hele emr-i muḳarrer ve ammā ' aḳỉb-i șalāt-

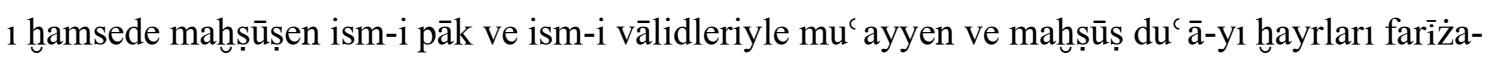

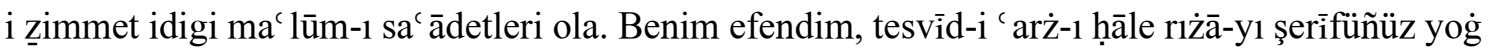
iken, bī-iḩtiyār taḥrīr-i 'ubūdiyyet-nāme eyledigim ' afv buyurasız ki va'llāhi ihtiyār ve șabr u ḳarār elimde degildür, lākin hāmil-i varaḳaya gāayet maḩfi iṣāl itmek bābında 'aẓim tenbīh ve tavșiye olunmışdur. Efendim, ben ḳuluña țaraf-1 ' âlīlerinden bir varaḳ-pāre degil, bir kelime gelse, iki üç güne dek dünyā gamını külliyen ferāmūş eyleyüp, envă‘ -1 neşậ u sürūr kesb eyledigim ma` lūm-1 devletleri oldıḳda, luṭf u ị̣sān efendimüñdür.

Sa ādetlü Selīm Aġa'mızuñ muḥabbet-nāmesi gelüp, cevāb1 irsāl olundı่̀1 zāhir-i ma` lūm-1 sa`ādetleri olmaḳ gerekdür. Șāniyen Evliyā Efendi ile sır-kātibi birāderi Mehememmed Beg'üñ dahi bir varaḳaları gelmiş idi. Ancak [18a] cevāba imkān-ı tahrīir olmadı.

Dünki gün sa' ādet-ḩāneden Evliyā Efendi ve Şeyḩ-zāde du' āciñuz ile ma' an 'Alī el-Ḥāc Çelebi-zāde'ye gelinüp, ahşāma bir sầ' at ḳala șoḥbet, ba' dehū bende-ḩāneye gelinmişdür ve Ḥelvācı geldikde, mecmū'a-i şerīfe elimde taḥīir olunmaḳda idi ve va'llāhu'l-`aẓim derūnum 'āleminde Ḥelvācı gelmesine yaḳinen beşāret ve ' alāmet var iken, fe-sübḥana'llāh içeri girdikde mebhūt-1 sürūr oldıg̀ım melḥūz-1 ‘ ālīleri ola.

\section{Beyt}

İstemez gülşen ü bezmi dil-i pür-ġam sensiz

Ne’yler ey ḥūr-liḳā cenneti Ādem sensiz

\section{Beyt}

Yārdan geldigi sā‘ atde nüvāziş-nāme

Māye-i ' ayş u dem oldı dil-i bi-ārāme

\section{Beyt}

Bā' iš-i sūr-1 sürūr oldı baña nāme-i yār

Eyledi cān ü dile feyż-i șafā nāme-i yār 
Kuhl idersem n'ola şevḳ ile sevād-1 ḥarfin

Çeşm-i giryāna virür nūr-1 żiyā nāme-i yār

\section{Beyt}

Āh kim yaḳdı kebāb itdi beni rūz-1 vedāc

Āteş-i dūzah imiş rūz-1 ciger-sūz-1 vedā‘ [18b]

beytleri nā-tamām olmag̉la, 'izz-i ḥużūra irsāl münāsib görülmedi. Benim efendim, bu varaḳpāreyi maḥall-i mahfifide oḳumaḳ kạābil ise oḳuyup, mümkin degil ise hemān iḥrāḳun bi’n-nār buyurasız. Nemiḳa-i 'āliyelerinde bir hāle girmişimdür ki görseñiz, bilmez idiñüz buyurulmış. Ḥaḳ te ālānuñ ḥıf̣ u emānında olasız. Ḳul, efendisini be'sen ü żarren ve dünyā vü 'uḳbāda bilmemek muhāaldür. Bilinmemek, ḳalbde olmamaḳdan iḳtiżā ider. Ben efendimüñ șūrī ve ma' nevī du ācısıyım. Ne ān ki görmemekle ferāmūş idem ve her ne ki varaḳa-i cān-bahşlarında işāret buyurulmışdur, emr ü fermān efendimüñdür. İnşā ’allāhu te ālā ḥayātda oldıḳça ihmāl ü tekāsül olunur degildür.

Hemān benim efendim, rābıța-i teveccühinizi ` āfitāb-1 ' ālem-tābdan zerre-i nāçīze düşen şu $\mathrm{a}-1$ merḥamet gibi dirīg eylemeyesiz ve dolābdan şey çıḳarurken bir mismār-1 küstāh mübārek dest-i şerífüñüzi āzürde eylemiş. Āh n'olaydı o mismār, benim sīneme zaḩm açup, efendime žerre ḳadar āzār u keder virmeye idi. İnşā ’allāhu te ālā ref ${ }^{\mathrm{c}}$-i derecāta işāretdür.

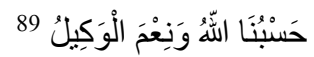

[19a] Benim efendim, sūz-1 derūnum ve aḥvāl-i iştiyāḳım, țab ${ }^{\complement}-1$ dakịika-dānlarına hafi degildür. Geregi gibi ‘ arż-1 iştiyāḳa mecāl ruhșat olmadı. İnşā’allāhu te āāā ceste ceste gazellerden ma' lūm1 sa' ādet olur. Ḩațt-1 müstekrehimiz ma` žūr olsun. 'İcāletü'l-vaḳt müzāḥeme-i züvvārdan nāşs̄ böyle olmışdur. İnşāa 'ü'l-Mevlā bundan böyle bir hoşça ifāde olunur, eger tesvīd-i 'ubūdiyyetnāmede cürmüm var ise merḥamet eyleyüp, 'afv eyleyesiz. Tehevvür ü gażab buyrulursa, ḳuluñuza mānic degil, ancaḳ efendime bā' iš-i keder olmaḳ havfın iderim. Mevlā her ḥālde efendimi zerre kederden emīn eyleyüp, her vaḳt ü ānlarda șafã vü şādmānī ile medīd ü mezīd eyleye.

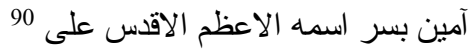

\footnotetext{
${ }^{89}$ Kur'ân-ı Kerîm, Âl-i İmrân Sûresi, 3/173, "Allah bize yeter. O ne güzel vekildir!"

90 "Yüce ve mukaddes olan ism-i azam sırrı için âmin."
} 
Cümle du âcılar, du' ālar iderler. Bāḳī hemiş̧e ḥıfẓ-1 İlāḥiyyede maḥfūẓ olup murād-ı dilh้ॅ̄āhları üzere mesrūr u kām-yāb olasız. Āmīn.

\section{[6. Mektup]}

\section{es-Selāmü 'Aleyküm [ve] Raḥmetu'llāhi [ve] Berekātühü}




budur ki mecmū a-i lațîfeleri bir def a irsāline işāret buyurulmış. Hezār şerm ile irsāl olundı, ma` żūr olsun Hुudā hakaḳıçün. Bir vech ile taḳșīe rıżā-dāde olunmadıġına ḳalb-i şerīfüñüz şāhidi 'ādildür. Ancaḳ keșret-i züvvār ve vefret-i ekdār işġāl eylemekden nāşī, dil-ḩ̌āh üzere imlā vü taḥrīre mesāg olmadi. Ancaḳ inşā'allāhu te`âlā șag olursaḳ el-eyyāmü beynenā birḳaç eyyām müțālac a olunduḳdan șoñra yine sebt ü taḥrīr olunur.

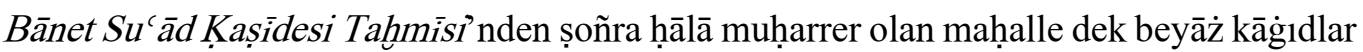
ḳonulmışdur. Makșūd Türkī ve Fārisī tahmīisleri tahrịir idüp, 'afvları mercūdur ve gazel-i mežkūr geregi gibi tafșil ve tersīl olsa gerek idi. Ancak bir vech ile ruhṣat-1 zamān olmadı. Luṭf idüp, her ne ḳadar ḳușūrum var ise ` afv buyrula.

\section{Rūy-1 zerdimden nişān bir șafḥa-i zỉbende var \\ Sābıḳan hūn-āb-1 eşkimden işāret var idi}

$\mathrm{Du}^{\prime}$ ācılaruñ bu bendeleri gibi ḩasteligi işāret buyurulmış Ḥaḳ te āla ḥıfẓ $[\mathrm{u}]$ emānında eyleye. Tafṣīl-i [20a] ḥāle muḥtāc, ancaḳ çāre ne? Bu dahi böyle olsun, ' unvān-1 mecmū' aya egerçi gümüş șuyı sürüldi, ancaḳ murād üzere taḥrīe imkān olmadı. Dünki gün -ki ibtidā-yı ' 1yd

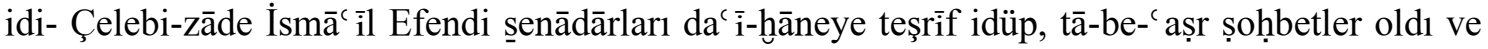
lākin ne çāre n'eyleyelim rūzgār elde degil ve ẓahr-1 varaḳada ḥammām ġazelcigi daḩi geregi gibi itmāma muvaffaḳ olmadıg ı̀ndan nāşī, mecmū' aya ḳayd olunmadı. Ancaḳ manẓūr-1 sa ādetleri olmaḳ için bu varaḳ-pāre ile irsāl-i pīşgāh-1 ' izzetleri ḳılındı.

Bir seḥer ḩ̌ābgehinden çıłup ol māh-1 tamām

İtdi mānend-i perī ‘ azm-i țarịk-1 ḥammām

Ġamzesinde eșer-i işve nümāyende-i nāz

Çeşm-i mestinde ' 1yān şive-i evżā' -1 menām

Beni biñ luṭf ile germ-ābeye teklïf itdi 
Oldı hem-rāh baña ol meh-i zībende-hyrām

Ḩāke oldıḳça ḳadem-sāy-1 tenezzül o perī

Reşk iderdi ten-i nāçīzine ārām-1 ḥarām [20b]

Cilvegāhında yüzüm ferş-i reh itsem kāşī

Tek hemān hāke o server itse vaż -1 aḳdām

Cāmeden eyledi ` ārī beden-i berrāḳuñ

Çıḳdı gūyā ki șadefden dür-i ferhunde-niẓām

Kılldı pūşīide siyeh fūtayı sīmīn tenine

İctimā` eyledi bir yerde o dem nūr u zalām

Peştemāl ile o māhuñ beden-i pür-tābı

Ḳ1dı zulmetde hemān āb-1 ḥayātı ihām

Nıṣf-1 hū̄rşīd yahūd girdi derūn-1 ebre

Şu le-i māhı füzūn eyledi yā ẓulmet-i şām

İtdi taḥvīl güneş yā Ḥamel ü Mīzān'a

Oldı gūyā ki leyāl ile berāber eyyām

Beden-i pākini bir ḥāl ile teşbīh idemem

Ki ne billūr u ne sīm ü ne muḳaşşer bādām

Pāy-1 zỉbāsına ferş eyledi rūyın na' leyn

Būs-1 aḳdāmına biñ şevḳ ile itdi iḳdām

Ten-i sīmīn[in]e ta' ẓìme döşendi mermer

Görüñ ol seng-dili itdi o sengīn dili rām

Ruh-1 hoy-gerdesi döndi gül-i şebnemdāna [21a]

Bülbül itdi beni bu ḥālet-i ḩayret-encām

Başına ḳubbelerüñ urdı buhāā-1 ḩayret 
'Ārıż oldı der-i dīvāra devār ü ser-sām ${ }^{91}$

Cümle çeşm oldı temāşā-yı cemāl anuñ içün

Șanma germ-ābede yer yer görünenler ola cām

Nahll-i kāfūr idi șan șafḥa-i sīmīn üzere

Șaḥn-1 mermerde ten-i sīm ile dil-dār be-nām

Çıkdı̇̀ı dem ser-i ḥammāma ḳıyāmet ḳopdı

$\mathrm{Na}^{c}$ ra-sāz oldı bu hengāme-i ḥasret-hengām

Pāyına cūy-1 sirişkim gibi āb oldı revān

Bürc-i ābīde idi șanki o şeb bedr-i tamām

İtdi mestūr ser-ā-pā beden-i sīmīnin

Eyledi șanki iḥāța meh-i tābānı gamām

Şişêei çeşm-i terim itdi gül-āb-efşāni

Ḳıldı tarțīb-i vücūd ol gül-i pākīze-meşām

'Arż idüp ḥażretine sūz-1 derūnın micmer

' $\bar{U} d$ bezl itdi vücūdın ġam-1 rāg̀ıbla tamām

' Āfiyet-ḩ̌ānı olup merdüm-i çeşm-i giryān

Ḳıldı ta` Ẓìm o şeh-i hü̈sne ahālì-i kirām [21b]

\section{Ġazel-i Dỉger}

Riżā-yı pāki üzre eyleyüp mevḳūf-1 şādānī

Nigehbānuñ ola şām u seḥerde ḥıf̣̂-1 Rabbānī

Beni endīşe-i rūz-1 vedāc uñ itdi şūrīde

Viṣālüñ gerçi dil-şād itdi birḳaç gün dil ü cānı

Şeb-i hasretde āh u girye itdikce niyāzım bu

\footnotetext{
${ }^{91}$ Metinde bu kelime “șer-şâm” șeklinde yazılmıș, ancak mânâ gereği yukarıdaki șekil tercih edilmiștir.
} 
Yine ḥayr ile göstersin Hudā'sı māḥ̂-1 tābānı

Dem-i vuṣlat eger biñ yıl olursa bir nefes gelmez

Velī biñ yıldan efzūndur firākuñ bir dem ü ānı

Gözüm nūrı seni yād eyledikce künc-i hasretde

Ne mümkin giryeden men` eylemek bu çeşm-i giryānı

Dem-i dil-sūz-1 hicrüñde görünce ża ${ }^{`}$ fımı bildim

Meger hicrān imiş bì-tāb iden bī-çāre insānı

Giriftārān-1 'aşḳa derd-i hicrān gibi derd olmaz

Ki ancaḳ vașl-1 cānāndur anuñ tedbīr-i dermānı

Senüñle külhan olsa cāygāhım reșk-i gülșendür

Dil-i şūrīde sensiz n'eylesin șaḥn-1 gülistānı

Esīr-i ' aşḳa cānān cāndan efzūn feyż-bahş oldı

Ger āh ister iseñ gör resm-i ḩaṭda cān u cānānı [22a]

Vücūd-1 nāzenīnüñ kām-yāb-1 ' āfiyet ḳ1lsın

Derūnuñdan Hudūā dūr eylesin ekdār u aḥzānı

Lisān ü kalbüñ eyle zikr ü fikr-i Hak ile ma'mūr

Enīsüñ zikr-i Ḥaḳ olsun celīsüñ fikr-i Rabbāni

Ne deñli dūr isem de luṭ̂-1 Ḥaḳ'dan nā-ümīd olmam

'İbād-1 mücrime çoḳdur Huudā’nuñ luṭf u ị̣sānı

Naḥifî̀-i garāibüñ șorma hâalin künc-i ḥasretde

Ḥużūr-1 ḥaşre dek eyler şeb [ü] rūzında efgāānı

Hemișe hı̣fz-1 İlāhīde olup ber-murād olasız.

$$
\begin{gathered}
\text { [7. Mektup] } \\
92 \text { ان ربنا لقدير على مايشاء }
\end{gathered}
$$

Göñül senden cüdā bir bülbül-i şūrīdedür gülsüz Ne bülbül gülden ayrılsın ne olsun gonce bülbülsüz

92 "Muhakkak bizim Rabbimiz, dilediği her şey üzerine gücü yetendir." 
İdüp ‘ arż-1 taḥassür eyle teblīig-i du' à bizden

Selām it ol nihāl-i bāg̀g-1 ḥüsne ey ṣabā bizden

Muḥabbetlü, meveddetlü, ḥaḳiḳatlü, șadāḳatlü a cānımdan 'azīzim efendim. Sulțānım ḥażretlerinüñ Ḥaḳ sübhānehū ve te ālā vücūd-1 nāzenīni[ni] belā [vü] żararlardan ve țab -1 laṭịf-i ṣad-āyīnini elem ü kederlerden emīn ü șālim [22b] eyleyüp, ber-vefḳ-1 murād sürūr-i ḳalb ve șafāyı ḩățir ve vuṣūl-i meḳaṣ̂d ile mesrūr u şād eyleye.

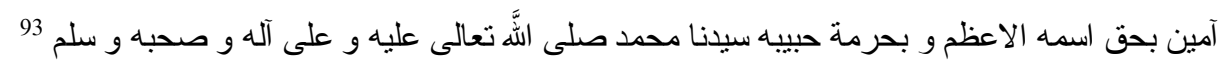

'Arż-1 ḥāl-i bende-i müştāḳ oldur ki, benim efendim, benim cānım içinde cānım, sulțānım. Bir, iki gün muhāālefet-i teşrīfüñi müşāhede itdikde, bu tehallüf ve ḩāşā bī-vefāyī vü hercāyīlik sulțānımdan oldı, ḳıāsıyla hāṭ̣rcıġım maḥūn olup, eyvāh bu ne bahtt-1 siyāhdur? Ben, efendimüñ


hayrını ve medh ü senāsını vird-i zebān itmiş iken:

\section{Beyt}

Mevc-ḩīz-i çīn-i nāz olmaḳda ebrūlarına

Fırșat-1 güftār bulmış gibi bed-gūlarına

diyerek efendim, bu ḳulından gaālibā rāżì olmayup, țabī' at-1 şerīi ḥaẓ itmemişdür. Çün ki hâāl böyledür "Görmemek yegdür görüp dīvāne olmaḳdan seni"" ${ }^{44}$ mı̣̣dāḳınca, bārī bir efendime görünüp, hāṭ̣̂r-1 şerīfini tekdīr ve ben 'abd-i müştāḳ dahi merḥametlü efendimi gördükçe derd-i ḥasretim efzūn ve āteş-i ' aş̣ [23a] u muḥabbetim ḥadden bīrūn olmaḳdansa, bārī cānım cebr idüp, birḳaç gün cemāl-i şerīfini görmekden perḩīz itmekle derdime dermān tesellì eyleyem, mülāḥaẓasıyla ḥattā mescid-i şerīfe bile varmaḳdan nefsimi keff idüp, künc-i hasretde āh u enīn ile șabr u taḥammüle ḳarār virmiş iken, el-hāmdüli'llāhi te ālā peyk-i ferhunde-maḳdem-i

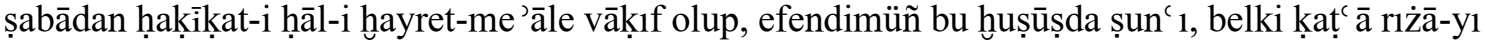
şerīfi olmayup, ḳabāḥat ve mel' anet ag̉yār-1 nādānuñ idigi ma' lūm-1 bendegī oldıḳda, efendime șıdḳ [u] muḥabbetim yüz ḳat ziyāde olup, șıdḳ u iḩlāṣla hayr dư āları tekrār olunmışdur. Benim و و تعالى ${ }^{2}$ بحمده سبحانه

\footnotetext{
93 "İsm-i azam hakkı için âmin. Sevgilisi, seyyidimiz $H z$. Muhammed hürmetine âmin. Allah ona, ailesine ve arkadaşlarına salât ve selam etsin."

94 "Vechi var kasdeylesem hicrinle ülfet etmeğe / Görmemek yeğdir, görüp divâne olmaktan seni." Bursalı Cinânî

95 "Yüce olana hamdetmekle, onu tesbih ve tenzih ederim."
} 
Ḥaḳkuñda müțālacam ve hüsn-i sīmāña muțābık luṭf-1 țab ve hüsn-i ḥālüñde mülāḥaẓamda hațā eylememişim. Benim efendim, benim sulțānım, hoş imdi öyle nādān yādigārlar ' ilm ü kemālüñ ve ma' ārif ü fażīletüñ ve erbābınuñ ḳadr ü şerefini [23b] ne bilür?

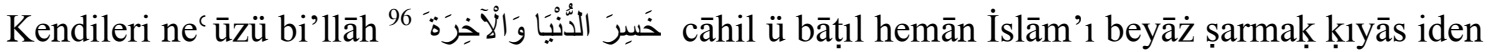
hayvāndan eḍall zümresinde bulunmışlar. Anlaruñ saña hükmleri şer` an ve ḳānūnen cārī degildür. Ancak ${ }^{97}$ hemān sen hüsn-i hālde ve talebde bulunup, peynirci ve gemici ve sā'ir alçaḳlar zümresinden iḥtirāz eyleyüp, hemān kendi kendüñe olsun. Bārīi, ' irfān ü ma' rifet țarafını elden ḳoma, anlar hayvāndan dahi eḍalldür. İnsān ḳadrini ne bilürler? c İlm ü ma rifet şerefini nice fehm iderler? Hoş imdi cenāb-1 Bārī celle şānuhu cezālarını virüp, ḳarīben kendileri nādim olurlar.

Benim her umūrum, Allāh-1 'aẓimü'ş-şāna tefvīì olunmışdur. İş odur kim Allāh oñara. Hemān benim meveddetlü efendimüñ ben bu bendesine, hüsn-i naẓarını ve gönülden ihrāc itmedigini [bildüre] ve gāh ki nigāh-1 luṭf u merḥamet ve nüvāziş-i hāạtır-1 maḥzūn içün fırṣat

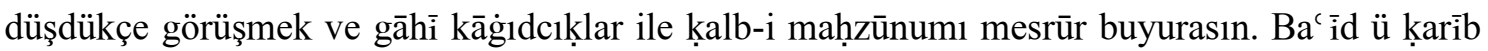
ben, efendimüñ hayr du āsındayım. Aġyār u ḥasūd, bildiklerinden [24a] ḳalmasın. Ben inkisārım ḳ1lıncını biñ kerre tecrübe eylemişimdür. Cümlesini Allah'a ḥavāle eyledim. Senüñ o nādāna virdigüñ cevābları işitdigimde, saña muḥabbetim biñ ḳat ziyāde olmışdur. Ber-huūrdār-1 'ömr olasın. Haḳ tec âlā devlet ü sa ādet ile senüñ dünyā ve āhiretüñ ma' mūr eylesin.

Dün șabāḥ yeñiçeri ag̉ası, bize gelirken yolda edeb ile selāma durdug̉uñ naḳl eyleyüp, saña vāfir du' ālar olundı. Benim efendim, bunuñ içinde saña yazup gönderdigim kāg̀idlar kemāli harāretimden ve gaayretden yazılmış idi. Ancak ha bir eglence olur, oḳuyup āteșe bıraġasın. Efendimüñ bu mertebe ḥaḳiḳatini bildikden șoñra cān u başımla māl ü mülkümle ḳulı, ḳurbānı olmaḳ üzerime vācib olmışdur. Efendim, ben senüñ ḳuluñ idigimi cümle a lā vü ednā bildiler. Hemān efendim, sen hemān ben ḳuluñı ḩâtı̣r-1 şerīfinden çıḳarma. Baña dahi lāzım olan, senüñ du ā-yı ḩayruñ hižmetidür. Rabbim ḳabūl eyleye, inşā'allāhu te` ālā. O saña dahll idüp mu āraża idenler, [24b] 'āḳıbet bir gün senüñ etegüñ öperler. Hemān ḳalbüñi dā 'imā Allāh'dan hāali ḳoma. Ancaḳ o yādigāruñ, senüñ benim meclisime geldigüñe ḳā'il olmadıg̀ı haylī gücüme gelmişdür. El-ḥamdüli’'lāhi te ālā benim meclise ḳāḍi efendi ve ag̉alar ve șı̣āā u kibārdan bu ḳadar ehl-i ' 1rż kimseler gelüp giderken o yādigār, "Ben senüñ oraya vardig̉uñ istemem” dimiş. Katı garāib gelür,

\footnotetext{
${ }^{96}$ Kur'ân-ı Kerîm, Hac Sûresi, 22/11, “... dünyasını da, ahiretini de kaybetmiştir.”

${ }^{97}$ Hadîs-i Şerîf: "Sabır, zaferin anahtarıdır.” Mehmet Yılmaz, Kültürümüzde Âyet ve Hadisler, Kesit Yay., İstanbul 2013, s. 593.
} 
ḩoş imdi yine kendisi kendi sözinden ve işinden utanur. Hemān șabr eyleyelim, Hudā ḳādirdür. Benim meclisimde ne maḳūle iḩtirāz idecek nesne gördi ve işitdi? Ḥattā seni, men`e sa`y ider. Ben el-ḥamdüli’llāhi te ālā İslāmı ve ' 'rżımı anuñ gibi mi bilürüm? Yā senüñ ‘rżuñu, dīnüñi ve sā'ir umūruñ benim gibi mi șaḳınur? Dahi beş gün içinde saña babalanması, kemāl-i hamāḳatinden idigi azhherü mine'ş-şemsdür ve tecrübe içün bir kerre 'ibādu'llāhdan ben ḳuluñı ve kendisini teftīş ve težkiye eylesin, ba' dehū görüşelim. Fe-sübhāana'llāhi'l-ḳādir.

Hāṣı11 efendim, ben seni bilirim ve senüñ [25a] muhabbet ve rıżānı isterim, gaayruñ sözi ve āvāzı yanımda dāne-i hardal degildür. Efendim sen hemān șag̉ ol, ben ḳuluñ göñlünden çıḳarma ve aralıḳda ān-1 vāḥide gelüp, ḳuluñla ülfet eylemek luṭf u merḥametine merhūndur. Ve du' ā dimişsin ki ne gūne du' ādur? Kāg̀id ile i` lām eyleseñ ki a benim efendim, çoḳ söyledim, mübārek başuñ ag̉rıtdım, ‘ afvuñ recā iderim.

Bāḳī hemīşe ḥıfẓ-1 Hudā'da maḥfuẓ olasın.



\section{[8. Mektup $]^{99}$}

Devletlü, 'ināyetlü, merḥametlü efendim, sulțānım ḥażretleri șag olsun. 'Arż-1 hāā-i dā‘ īleridür ki bu dā‘ îleri, 'illet-i gurbet derūnumda iken nihāyetinde 'illet-i süknā ile șig̀ga-i vücūdum, lefíf-i maḳūna müşābehetle emșile-i ' unșurum, 'ilel [ü] emrāżdan șahịh ü sālim olmayup, te` āḳub-1 ḳażā-yı āsümāni ile ālām u ekdārım mużā‘ af olmag̉la, aḳānım [25b] beyninde müsteșkal ve bu 'illet ile 'aḳlım nāḳıṣ ve derūnum ecvef-i vāvīye mis̄āl ve zihnim ḳarışıḳ, ism-i fācil ve rūz u şeb emșile-i muhtelife gibi ekdārım gūn-ā-gūn olup, yersizlikden țalebe beyninde cümle-i mu' teriże gibi i' rābdan bī-mahal ve bir bināya 'āmil bul[un]madıġımdan cerr-i civārīye muhtāc olup ve mübhem olmam ile tekellümāya żamīrimi ibrāz ide[cek] bir merci` bulmayup ve ismim mübhem-i tām olmag̉la hậ̄limi temyīze naṣb-1 nefsì ider bir ehl-i hayra sevḳ olunmayup, velākin gibi hiffet ile 'aḳlım 'amelden ḳalup ve naẓm-1 a'zāararım ve zihāf-1 'ilelden gayrı bir ma' nāya dāl, baḥr-i mütedārik gibi cümleden huurūc ile șaḥihü̉'l-bāl olmayup, bu hayālātla ḳuvāyı bāṭnem cüz’iyyāt-1 efkārla māl-ā-māl ve nefs-i nāṭkam, idrāk-i külliyāta bī-mecāl olmag̉la ḥadd-i zāâtında 'avārıż-1 māhiyyetimi ta' rīf ve rüsūm-1 ādāb üzere beyānla bār-1 ekdārımı tahfiffden

\footnotetext{
98 "Eğer âşıkāne bir şekilde yüz mektup yazarsam sana olan arzumdan yüz yıl kalır, hikâyesi sonsuz olur."

${ }^{99} \mathrm{Bu}$ mektupta, tenasüp sanatı açısından birbirleriyle ilgili olan kelimeler vurgulu yazılmıştır.
} 
'āciz olup, bu terekküb-i ḳażāyā-yı ser-güżeştim bürhān-1 innī-i meşiyyet tahaḳḳuḳ-1 hümūm ve manț̣k-1 kelāmım aḥvālimi müntic şekl-i evvel gibi mi' yār-1 'ulūm ve bir beyt-i mu' dimāt-1 tedbīirim şekl-i sāāi gibi șayhun le in merāne ${ }^{100}$ olmasından [26a] mā' adā șūret-i cismiyem dahi işbāt-1 münāsebet-i 'arż-1 ḥāle delīl-i lemmīdür ki gumūm [u] ekdār ile kemāl-i ża' fimdan șūret-i nev iyyetim daḩi heyūlān-1 șayhun le 'in merāne ve ḥadeḳa-i çeşmim dīde-i mevhūme ve merdümi dīdelerim, cüzün lā-[ye]tecezzā ve levḥ-i sīnem ușturlāb ve hey'et-i ḳāmetim küre-i eflāke dönmişdür ve bu edille-i ḳaț iyye ḳıyās-1 fiḳhī gibi aḥkām-1 aḥvālimi müs̄bit degilse de muẓhirdür. Gerçi naẓm-1 kelāmım ifāde-i merāmda hafî̀ ve mücmel ve müteşābih [ü] mübhem, lākin nașs-1 vücūdum bu ma' nāya delāletde zāhir ve müfesser ve muḥkem, binā'en 'aleyh bu bābda ḳașr-1 ḳalb idüp, bir hâali müderresde (?) tāc-1 saḳfdan seri c uryān ve harḳa(?)-i cidārı haraīị ve perīşān ve ātȩ̣-i miḥnetden derūnı sūzān ve çeşm-i revzenleri bārān-1 belā ile giryān bir oța var ki ta mīri, baḥr-i ḩayrı bì-pāyān bir ehl-i iḥsān luṭfından bende-i 'ummān olup, binā-yı saḳf [u] cidāra emr [ü] fermān devletlü, ' ināyetlü, merḥametlü efendim sulțānım ḥażretlerinüñoür.

\section{Kaynaklar}

Abdulkadiroğlu, A. (1994). İsmâil Beliğ. Nuhbetü'l-âsâr; Ankara: AKMB Yay.

Abik, A. D. (1993). Ali Şî̀ Nevâŷ̀’nin risâleleri: târîh-i enbiyâ ve hükemâ, târîh-i mülûk-i Acem, münşeât (Metin- gramatikal indeks-sözlük). Yayımlanmamış doktora tezi. Ankara: Ankara Üniversitesi Sosyal Bilimler Enstitüsü.

Açık, N. (2006). Nahîfî, Türk dünyası edebiyatçıları ansiklopedisi. Ankara: AKMB Yay., 2006, C. 6 .

Ahmed, R. (1300). Lügât-ı târihiyye ve coğrafiyye. İstanbul: 7.

Akbayar, N. (1996). Mehmed Süreyyâ, sicill-i Osmânî. İstanbul: Tarih Vakfı Yurt Yay., 1996.

Akkuş, M. ve Yılmaz, A. (2011). Hüseyin vassâf, sefine-i evliyâ. İstanbul: Kitabevi Yay., 5.

Araç, G. Tokatlı Kânî’nin Münşeâtı ve İncelemesi. Yayımlanmamış doktora tezi, İzmir: Ege Üniversitesi Sosyal Bilimler Enstitüsü.

Aypay, A. İ. (1992). Nahifi Süleyman Efendi (Hayatı, eserleri, edebî kişiliği ve divanının tenkitli metni). Konya: Selçuk Üniversitesi Sosyal Bilimler Enstitüsü.

Bağdatl1, İ. P. (1951). Hediyyetü'l-Ârifin, esmâ 'ü'l-müellifin ve asârü'l-musannifin. (tashih: K. Rifat Bilge-İbnülemin M. Kemâl). İstanbul: Millî Eğitim Basımevi, 1.

\footnotetext{
${ }^{100} \mathrm{Bu}$ kelime grubu aynı mektup içinde iki kez geçmektedir. Okunuşunda tereddüt edildiğinden asıl şekli de bildirilmiştir:

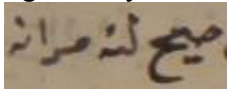


Bursalı M. T. (1333). Osmanlı müellifleri. Dersaadet, C. II.

Ceyhan, Â. (1997). Süleyman Nahîfî ve kasîde-i mudariyye tahmisi. Urfa: Akademik Bakış, Güz.

Ceyhan, Â. (2000). Süleyman Nahîfî’nin Mevlidü'n-Nebî mesnevîsi. Erzurum: Atatürk Üniversitesi Türkiyat Araştırmaları Enstitüsü Dergisi, 14.

Ceyhan, Â. (2010). Ahmed Paşa'ya bir isnad dolayısıyla divan şiirinde aşkın niceliği. Bursalı Şair Ahmed Paşa ve Dönemi, Editör: Bilal Kemikli.

Çapan, P. (2005). Mustafa Safâŷ̀,tezkire-i safâŷî. Ankara: AKMB Yay.

Çelebioğlu, Â. (1967). Mesnevî-i Şerîf: aslı ve sadeleştirilmişiyle manzum Nahifî Tercümesi. İstanbul: Sönmez Neşriyat, 1.

Çelebioğlu, Â. (1972). Süleyman Nahîfî ve fazilet-i savm (Zuhrü'l-Ahire) adlı eseri. Ankara: Diyanet Dergisi, 12.

Çelebioğlu, Â. (1987). Süleyman Nahîfî’nin Hicretü’n-Nebî'nin adlı mesnevîsi. İstanbul: Türklük Araştırmaları Dergisi, 2.

Çelebioğlu, Â. (1998). Nahîfínin Risâle-i Hıdriyye'si Eski Türk Edebiyatı Araşstırmaları. İstanbul: MEB Yay.

Çiftçi, Ö. (2014). Fatin Davûd, Hâtimetü’ l-Eş 'âr. Kültür Bak. e-kitap:

Çomar, A. (2001). Süleyman Nahifi, Enfüsü'l-Afak. Yayımlanmamış yüksek lisans tezi, İstanbul: Marmara Üniversitesi Sosyal Bilimler Enstitüsü.

Develi, H. (1998). XVIII. yy. İstanbul'a Dair Risâle-i Garibe. İstanbul: Kitabevi Yay.

Durmuş, İ. (2000). İnşâ, Diyanet İslâm ansiklopedisi. İstanbul, 22.

Ekinci, R. (2013). Hâfız Hüseyin Ayvansarâyî, Vefeyât-ı Ayvansarâŷ̂. İstanbul: Buhara Yay.

Er, Ş. (2014). Nahîfî Süleymân Efendi külliyâtı. İstanbul: Kutupyıldızı Yay.

Erdoğan, M. (2011). Türk Edebiyatında Manzum Hilyeler. Yayımlanmamış doktora tezi. Sivas: Cumhuriyet Üniversitesi Sosyal Bilimler Enstitüsü.

Esir, H. A. (2006). Münşeât-ı Lâmiî: (Lâmî̀ Çelebi'nin mektuplarl) - inceleme - metin - indeks sözlük. Trabzon: Karadeniz Teknik Üniversitesi Yay.

Fâik R. (1312). Eslâf. İstanbul: 'Âlem Matba'ası, C. 2.

Fındıklı1ı İ. (1989). Tekmiletü'ş-şakā'ik fî ehli'l-hakā'ik. (tıpkıbasım: A. Özcan), İstanbul: Çağrı Yay.

Gibb, E. J. W. (1999). Osmanlı şiir tarihi (çev. A. Çavuşoğlu). Ankara: Akçağ Yay., 3.

Gökyay, O. Ş. (1974). Tanzimat dönemine değin mektup. Türk Dili Dergisi Mektup Özel Sayıs1, (30)274.

Gölpınarlı, A. (1955). Divan şiiri, XVIII. Yüzyıl. İstanbul: Varlık Yay. 
Güzel, B. (2012). Kemiksizzade M. Safvet, Nuhbetü'l-Âsâr min Ferâidi'l-eş 'âr isimli şairler tezkiresi. Yayımlanmamış yüksek lisans tezi, Ankara: Gazi Üniversitesi Sosyal Bilimler Enstitüsü.

Haksever, H. İ. (1995). Eski Türk edebiyatında ömünşeâtlar ve Nergisî’nin Münşeâtı. Yayımlanmamış yüksek lisan tezi, Malatya: İnönü Üniversitesi Sosyal Bilimler Enstitüsü.

Haksever, H. İ. (2001). Veysî ve Nergisî’nin karsılıklı mektupları. Afyon Kocatepe Üniversitesi Sosyal Bilimler Dergisi 2.

Haksever, H. İ. (2011). Nâbî münşeâtında mizahi ifadeler ve Râmî Paşa'ya yazdığı mizahi mektup, Turkish Studies, (6)2.

http://www.turkedebiyatiisimlersozlugu.com/index.php?sayfa=detay\&detay=2663 [erişim tarihi: 01.11.2014]

İnal, İ. M. K. (1928). Müstakimzâde Süleyman sa'deddîn, tuhfe-i hattâtîn. İstanbul: Devlet Matbaas1, 1928.

İnce, A. (2005). Sâlim efendi, Tezkiretü'ş-Şu 'arâ. Ankara: AKMB Yay.

İpekten, H. vd. (2002). Şair tezkireleri. Ankara: Grafiker Yay.

Kaplan, M. (1999). Divan şiirinde kadın aşk yok mudur? Osmanlı Divan Şiiri Üzerine Metinler. (haz. Mehmet Kalpakl1), İstanbul: Yapı Kredi Yay.

Karaca, Y. (1997). Süleyman Nahifi Efendi ve mevlidi. Yayımlanmamış yüksek lisan tezi, Ankara: Ankara, Üniversitesi Sosyal Bilimler Enstitüsü.

Karaman, H. (2001). Lâmi 'î Çelebi'nin münşeâtı. Yayımlanmamş yüksek lisans tezi, Afyon: Kocatepe Üniversitesi Sosyal Bilimler Enstitüsü.

Karavelioğlu, M. (2014). Nahîfî Süleyman. Türk Edebiyatı Ísimler Sözlüğ̈̈

Keskinsoy, H. (2011). Mekkî ve Nahifí'nin kaside-i bürde tahmisleri. Yayımlanmamış yüksek lisans tezi, Kahramanmaraş: Sütçü İmam Üniversitesi Sosyal Bilimler Enstitüsü.

Kılıç, A. Münşe'at-ı Veysî (İnceleme-transkripsiyonlu ve tenkitli metin). Devam eden doktora tezi, Kayseri: Erciyes Üniversitesi Sosyal Bilimler Enstitüsü.

Komisyon (1986). Nahîfi Süleyman Türk Dili ve Edebiyatı Ansiklopedisi. İstanbul: Dergâh Yay., 6.

Levend, A. S. (1984). Divan edebiyatı. İstanbul: Enderun Kitabevi.

Levend, A. S. (2008). Türk edebiyatı tarihi. Ankara: TTK Yay.

Muallim N. (1307). Osmânlı şấ irleri. İstanbul.

Muallim N. (1308). Esâmî. İstanbul.

Müstakimzâde S. Sa‘deddîn, Mecelletü’ n-Nisâb. Süleymaniye Ktp., Hâlet Efendi, nr. 628.

Oğraş, R. (2014). Es 'ad Efendi, bağçe-i safâ-enduz. Kültür Bak. e-kitap: 
Oktay, A. (2014). Nâbî'nin münşeât'ı: İnceleme-metin. Yayımlanmamış doktora tezi, Diyarbakır: Dicle Üniversitesi Sosyal Bilimler Enstitüsü.

Özkırımlı, A. (2004). "Nahifî Süleyman”, Türk Edebiyatı Tarihi (Ansiklopedisi). İstanbul: İnkılap Yay., 2.

Şemseddin S. (1316). Kāmûsü'l-A'lâm. İstanbul: Mihran Matbaas1, 6.

Tuman, M. N. (2001). Tuhfe-i Nâilî, (tıpkıbasım: C. Kurnaz-M.Tatcı). Ankara: Bizim Büro Yay., 2.

Uludağ, Süleyman (1997). Tasavvuf Terimleri Sözlüğü. İstanbul: Marifet Yay.

Usluer, Zekeriya (hzl.), (1994). Süleyman Nahifi Hayatı, Eserleri ve Hilyetü'l-envar'ı. Yayımlanmamış yüksek lisans tezi, İstanbul: Marmara Üniversitesi Sosyal Bilimler Enstitüsü.

Uzun, M. (2006). "Nahîfî”, Diyanet İslâm ansiklopedisi. İstanbul, 32.

Yasav, O. (1995). Hilyetü'l-Envar. Yayımlanmamış yüksek lisans tezi, İstanbul: Marmara Üniversitesi Sosyal Bilimler Enstitüsü.

Yılmaz, M. (2013). Kültürümüzde âyet ve hadisler. İstanbul: Kesit Yay.

Yöntem, A. C. (1927). On ikinci asr-1 edebî’nin meşhûr sîmâlarından Süleymân Nahîfî. Hayat Mecmuası, 22.

Ziyâ, P. (1311). Mukaddime-i harâbât. İstanbul: Matba'a-i Ebuzziyâ.

Zübeyiroğlu, R. (1989). Mehmed Tevfik Efend, mecmuatü't-terâcim. Yayımlanmamış doktora tezi, İstanbul: İstanbul Üniversitesi Sosyal Bilimler Enstitüsü. 